\title{
UNVEILING THE CONSEQUENCES OF ENVIRONMENTAL VARIATION AND SPECIES ABUNDANCES ON BEACH TAPHOFACIES IN BAHAMAS: THE ROLE OF CEMENTATION AND EXHUMATION
}

\author{
SOL BAYER, ${ }^{1,2}$ DIEGO BALSEIRO, ${ }^{1,2}$ DIEGO F. MUÑOZ, ${ }^{1,2}$ AND SANDRA GORDILLO ${ }^{1,2}$ \\ ${ }^{1}$ Facultad de Ciencias Exactas, Físicas y Naturales, Universidad Nacional de Córdoba, Argentina \\ ${ }^{2}$ Centro de Investigaciones en Ciencias de la Tierra, (CICTERRA), CONICET and Universidad Nacional de Córdoba, Edificio CICTERRA, Av. Vélez Sársfield 1611, \\ X5016CGA, Ciudad Universitaria, Córdoba, Argentina, \\ email:sol.bayer@conicet.gov.ar
}

\begin{abstract}
Although environmental variability generates differences in the preservation of shell assemblages, intrinsic variations in shell characteristics can confound the effects of environment on preservation. However, several studies proposed that the composition of shell supply only affects the intensity of alteration but not its preservation trend along the environmental gradient and that environmental variability represents a major driver of taphofacies preservation. Here, we examine whether taphonomic differences among four infaunal and aragonitic bivalve species differing in shell thickness affect the definition of beach taphofacies in tropical carbonate environments on San Salvador Island (Bahamas). We show that (1) taphofacies can be discriminated with respect to (a) wave and storm activity as a function of exposure to Trade Winds, and (b) sandy beaches versus beaches with a mixture of sands and beach rock (representing a source of exhumed and cemented shells), and (2) species-specific bivalve assemblages show similar gradients in preservation, documenting that differences in preservation between species have minor effects on taphonomic discrimination of beach environments. Environments with a mixture of sands and beach rock are characterized by higher frequency of external cementation and abrasion than sandy beaches. Shells from low-energy beaches are more fragmented and discolored than shells from high-energy beaches. Previous studies showed that shells from San Salvador sandy beaches are more time-averaged than shells from rocky beaches. Differences in preservation between these two environments indicate two pathways: (1) assemblages on sandy beaches are degraded at higher rate but are enriched by old exhumed and lithified shells, and (2) assemblages on rocky beaches are cemented at higher rate. Old and lithified shells on sandy beaches are probably derived from submerged or exposed beach rock patches, leading to the mixture of young, well-preserved shells with old, poorly preserved shells. Shells on sandy beaches thus experience a complex history of burial and exhumation before their final deposition. Therefore, shell assemblages in lower energy carbonate environments from San Salvador Island are highly time-averaged, with the presence of old, poorly preserved shells. The depositional environment is thus the dominant factor controlling the structure of San Salvador beach taphofacies.
\end{abstract}

\section{INTRODUCTION}

Preservation patterns of fossil assemblages are often affected by environmental factors; comparative and quantitative taphonomical analyses of fossil assemblages have, therefore, been useful as a basis for reconstructing paleoenvironments (Speyer and Brett 1988; Smith and Nelson 2003; Best 2008; Darroch et al. 2016; Ritter et al. 2019). One of the tacit assumptions of taphofacies analyses is that preservation pathways of skeletal remains differing in durability or susceptibility to alteration are similar (Kidwell and Flessa 1996; Behrensmeyer et al. 2000; Zuschin et al. 2000; Staff et al. 2002; Powell et al. 2011). In a scenario where all species show identical responses to taphonomic processes in each given environment (Fig. 1A), taphofacies can be defined on the basis of multispecies assemblages and used to characterize environmental conditions regardless of their taxonomic composition (Callender et al. 2002; Staff et al. 2002; Brett et al. 2011; Powell et al. 2011). However, differences in shell durability and population dynamics (e.g., extinction of formerly abundant species will lead to over-representation of old cohorts with high alteration) also exert some control on the taphonomic signature of multi-species death assemblages (Allmon 1993; Best and Kidwell 2000b; Powell et al. 2002; Lazo 2004; Tomašových 2004; Tomašových and
Rothfus 2005), especially in tropical carbonate environments that are prone to significant time-averaging and taphonomic inertia (Kosnik et al. 2007, 2013; Albano et al. 2016; Ritter et al. 2017; Gilad et al. 2018 but see Feser and Miller 2014; Martinelli et al. 2016). Both laboratory experiments (Chave 1964; Wainwright 1969; Glover and Kidwell 1993) and field observations (Best and Kidwell 2000a, 2000b; Tomašových and Rothfus 2005) corroborated this pattern. Hence, species can show contrasting taphonomic signatures that are not caused by different environmental factors but by intrinsic differences between them, including differences in life habit, mineralogy, or shell organic content. For example, infaunal bivalves can experience a better shell condition if they remain within the sediment after their death than epifaunal bivalves (Lazo 2004). Shape, symmetry, size, and ornamentation of shells provide a hydrodynamic signature that can induce taphonomic bias by selective transport and create problems for analyses of biodiversity (Cadée 1968; Cummins et al. 1986; Olszewski and West 1997; Chattopadhyay et al. 2013). If these intrinsic factors are so important that each taxon records a completely different pattern of damage in different environments, then paleoenvironmental inferences based on the taphofacies concept can be inaccurate. For example, Tomašových and Zuschin (2009) found that shell-thickness 


\section{Energy / Environmental gradient}
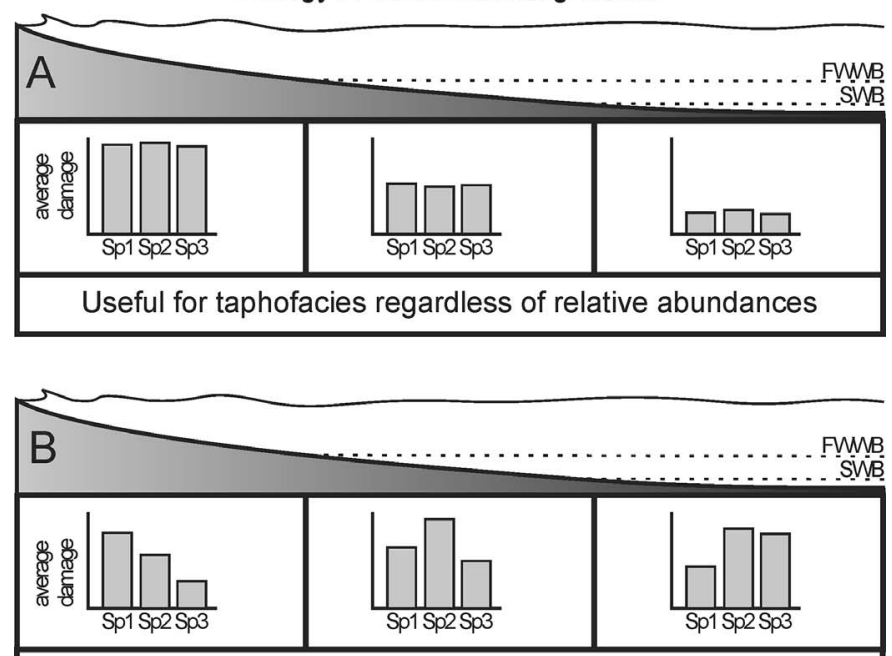

Not useful for taphofacies regardless of relative abundances

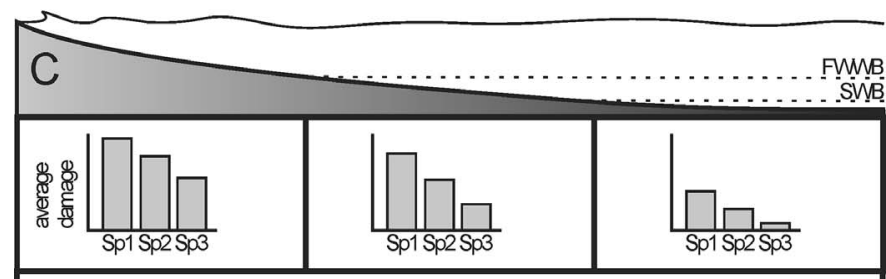

Useful if small changes in relative abundances Not useful if large changes in relative abundances

FIG. 1.-Three possible scenarios to explain the influence of intrinsic variation on the definition of taphofacies. A) No intrinsic differences, species behaved equally to the environmental gradient. B) Substantial intrinsic differences. C) Species behaved qualitatively similarly but quantitatively differently to the environmental gradient.

differences between brachiopod species generated differences in damage. In an extreme hypothetical scenario, taphofacies types would not reflect environmental differences but differences in the composition of death assemblages (Fig. 1B).

The latter scenario may be, however, not very likely. Best and Kidwell (2000a, 2000b) have shown that in the Caribbean, shell assemblages of the different species differing in life habit, shell thickness, shell mineralogy, and microstructure along environmental gradients show identical patterns of damage in terms of rank order of taphonomic variables and differ only in the absolute intensity of damage. Therefore, it was hypothesized that the intrinsic variation primarily affects the intensity of the taphonomic signature and does not distort the environmental significance of taphofacies (Best and Kidwell 2000a, 2000b; Staff et al. 2002; Powell et al. 2011).

Although these results are promising for taphofacies analysis, they do not mean that taphofacies are free from the intrinsic biological effects that could reduce their correlation with environmental gradients. Taphofacies can differ simply because of different relative abundances of species that differ in their intrinsic durability. If species with different taphonomic responses differ dramatically in their abundances among rather similar environments, especially due to patchiness that is typical of shallow carbonate environments, different taphofacies can be identified within the same environment. The opposite scenario can also be present, where the same taphofacies characterizes different environments (e.g., if inhabited by generalist species inhabiting different habitats), obscuring true environmental differences (Fig. 1C).

The four species that we targeted here are shallow-infaunal, aragonitic, with similar shell size and similar microstructure and shell organic content. However, they differ in shell thickness and in environmental distribution. Therefore, we assess whether differences in thickness and differences in species abundances affect discrimination of (1) taphofacies and (2) biofacies in beach environments varying in the exposure to waves and storms and in sediment grain size. First, the eastern coast of San Salvador faces the open ocean while the west side faces the Bahamas Bank. Therefore, local communities can be expected to show preservational and compositional differences mirroring such geographical variation. Second, presence or absence of beach rock patches in the beach (sandy and beach rock environments) can also generate differences (1) in preservation owing to differences in residence time in the taphonomic active zone and in the susceptibility to cementation (i.e., beach rock is characterized by fast cementation; Kindler and Bain 1993), and (2) in the relative abundance of taxa because bivalves are sensitive to differences in substrate consistency (Stanley 1970; Fürsich and Flessa 1987; Kidwell and Flessa 1996; Best and Kidwell 2000a). Pruss et al. (2011) found that San Salvador bivalve assemblages on sandy beaches are more time-averaged than more altered bivalves on rocky beaches, providing an opportunity to test whether this pattern is sensitive to species identity. In this contribution, we assess how differences in species relative abundances between environments affect their separation on the basis of their taphonomic patterns, and whether they allow definition and interpretation of taphofacies from beaches with deposition of sands and beach rock on San Salvador Island in the Bahamian Archipelago. For example, beach rock can be characterized by unique taphonomic signatures owing to early cementation (Feige and Fürsich 1991). To address this objective, we (1) analyze taphofacies in four different beach environments, (2) assess intrinsic between-species differences in the rank order and intensity of taphonomic attributes, (3) estimate whether the differences in species' relative abundances affect the discrimination of taphofacies, and (4) measure the correlation between taphofacies and biofacies to resolve their power in environmental discrimination.

\section{Study Area}

The Bahamas Archipelago is located in the tropical West Atlantic. San Salvador Island is an outer island in the Bahamas located at $24^{\circ} 3^{\prime} \mathrm{N}$ latitude and $74^{\circ} 30^{\prime} \mathrm{W}$ longitude (Fig. 2). It is surrounded by a narrow shelf with an abrupt shelf-edge break leading to a very steep slope that is $4,000 \mathrm{~m}$ deep (Curran et al. 1993; Gerace et al. 1998). The northeasterly Trade Winds primarily control wave energy on the Grand Bahama Bank (Wright and Burchette 1996; Horwitz and Roberts 2010). The Bahamas are exposed to significant hurricanes and tropical storms from the North Atlantic. These violent storms cause shore erosion of many islands (Buchan 2000) and sediment distribution and dispersal, particularly along western margins (Wright and Burchette 1996). Nearshore waters of the island are affected by strong currents (long-shore currents) and by waves that are forced by easterly winds from the Atlantic Ocean (Gerace et al. 1998; Horwitz and Roberts 2010). Moreover, easterly winds and hurricanes produce progradation of many beaches in summer (Gerace et al. 1998; Bishop and Greenstein 2001; Horwitz and Roberts 2010), particularly eastern beaches may be prograding more rapidly than in other areas (Beier 1985).

Depending on the amount of consolidated substrates or exposed rock in the intertidal zone on San Salvador Island, some foreshore areas are characterized by a broad sandy beach without any exposed beach rock, while other foreshore areas consist of varying proportions of rocky and sandy patches (Fraser and Greenstein 1993; Pruss et al. 2011). On the east side of San Salvador Island, beach rock is almost absent and beach sands are fine to very fine-grained (Beier 1985; Clark et al. 1989). 


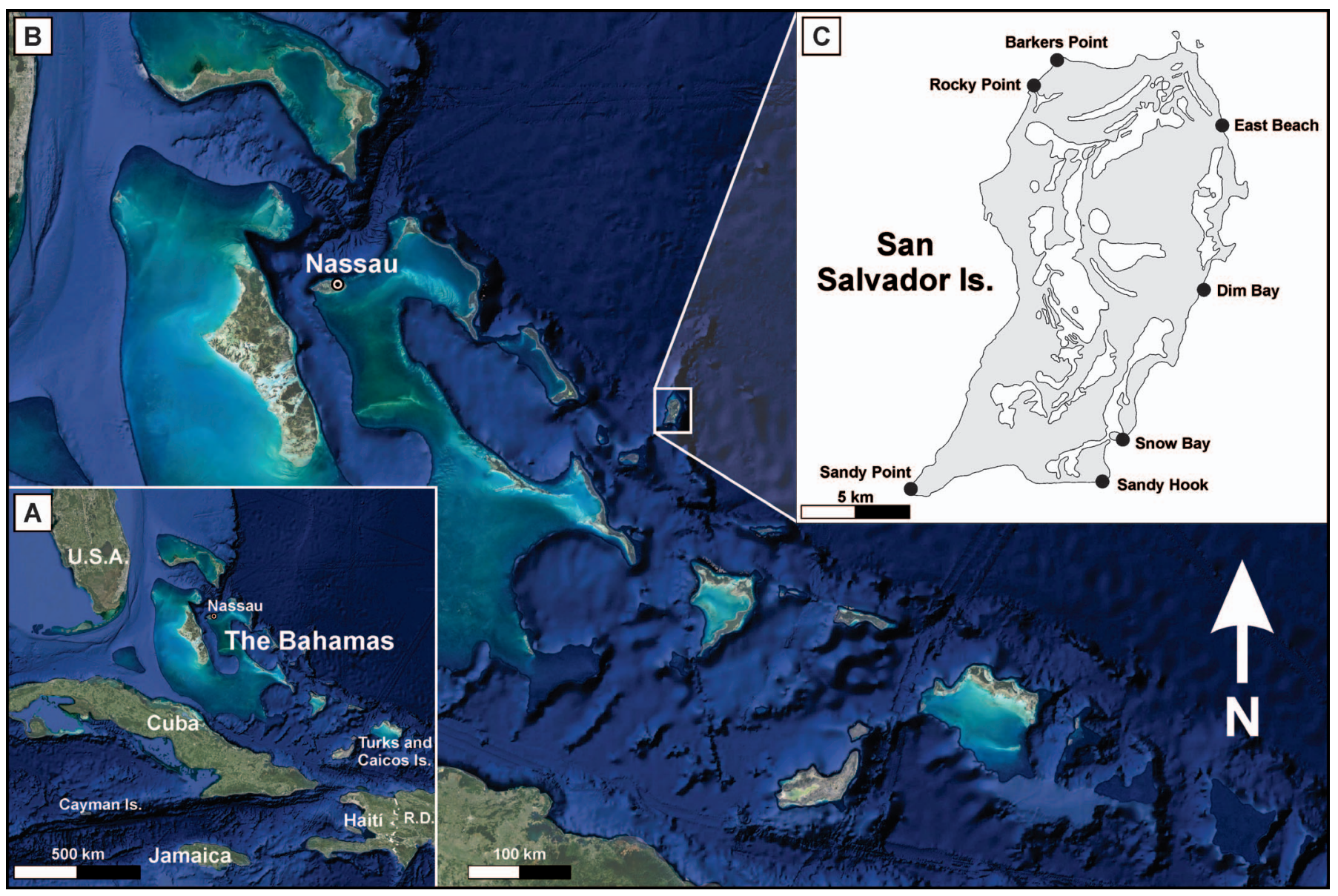

FIG. 2.-Location map showing San Salvador Island in the Bahamas archipelago. Dots correspond to beaches where sampling was performed.

\section{MATERIALS AND METHODS}

\section{Sampling}

Seven localities (Fig. 2) were classified into two groups on the basis of their geographical position with respect to Trade Winds and thus in terms of their exposure to wave and storm activity. Four of them were located on the windward coast (i.e., high-energy environment) of the island, namely East Beach, Dim Bay, Snow Bay, and Sandy Hook. The other three localities, namely Barkers Point, Rocky Point, and Sandy Point were located along the leeward coast (i.e., low-energy environment) (Table 1)

Localities were also classified based on the presence or absence of active beach rock patches. Two sites were sandy beaches (Sandy Point and East Beach). The remaining five sites had rock patches present and were labeled rocky. Sandy Hook and Dim Bay showed significant reworking of sand and large boulders of beach rock, Barkers Point had only few beach rock patches (Carney et al. 1991; Kim 2001; Thomason et al. 2005; Buchan 2006) (Table 1).

Sampling was performed during low tide in summer 2010. Two equidistant transects (120 meters distant) were laid at each locality, both were perpendicular to the shore (14 transects in total). Each transect was measured and sampled. The first sample was taken from the beach zone and farthest from the shore, where the third sample was taken; the second sample was equidistant between them. A third transect was laid at each locality in the intertidal zone and consisted of six samples (Fig. 3). In total, eighty-four samples were collected by hand from $1 \mathrm{~m}^{2}$ surface quadrats.
TABLE 1.-List of sampling sites at San Salvador Island. Beach type was coded according to the substrate and geographic position. East beaches are in windward (high energy) while west beaches are in leeward (low energy) position.

\begin{tabular}{|c|c|c|c|c|}
\hline Locality & Coordinates & $\begin{array}{l}\text { Geographic } \\
\text { position }\end{array}$ & Substrate & Beach type \\
\hline Barkers Point & $\begin{array}{l}\text { N } 24^{\circ} 7^{\prime} 11.89^{\prime \prime} \\
\text { W } 74^{\circ} 30^{\prime} 25.44^{\prime \prime}\end{array}$ & West & rocky & Rocky low energy \\
\hline Dim Bay & $\begin{array}{l}\mathrm{N} 24^{\circ} 1^{\prime} 13.73^{\prime \prime} \\
\mathrm{W} 74^{\circ} 27^{\prime} 4.17^{\prime \prime}\end{array}$ & East & rocky & Rocky high energy \\
\hline East Beach & $\begin{array}{l}\text { N } 24^{\circ} 5^{\prime} 27.91^{\prime \prime} \\
\text { W } 74^{\circ} 26^{\prime} 21.80^{\prime \prime}\end{array}$ & East & sandy & Sandy high energy \\
\hline Rocky Point & $\begin{array}{l}\text { N } 24^{\circ} 6^{\prime} 27.54^{\prime \prime} \\
\text { W } 74^{\circ} 31^{\prime} 5.94^{\prime \prime}\end{array}$ & West & rocky & Rocky low energy \\
\hline Sandy Hook & $\begin{array}{l}\text { N } 23^{\circ} 56^{\prime} 54.77^{\prime \prime} \\
\text { W } 74^{\circ} 29^{\prime} 16.81^{\prime \prime}\end{array}$ & East & rocky & Rocky high energy \\
\hline Sandy Point & $\begin{array}{l}\text { N } 23^{\circ} 56^{\prime} 40.63^{\prime \prime} \\
\text { W } 74^{\circ} 34^{\prime} 11.04^{\prime \prime}\end{array}$ & West & sandy & Sandy low energy \\
\hline Snow Bay & $\begin{array}{l}\text { N } 23^{\circ} 57^{\prime} 51.17^{\prime \prime} \\
\text { W } 74^{\circ} 29^{\prime} 2.57^{\prime \prime}\end{array}$ & East & rocky & Rocky high energy \\
\hline
\end{tabular}




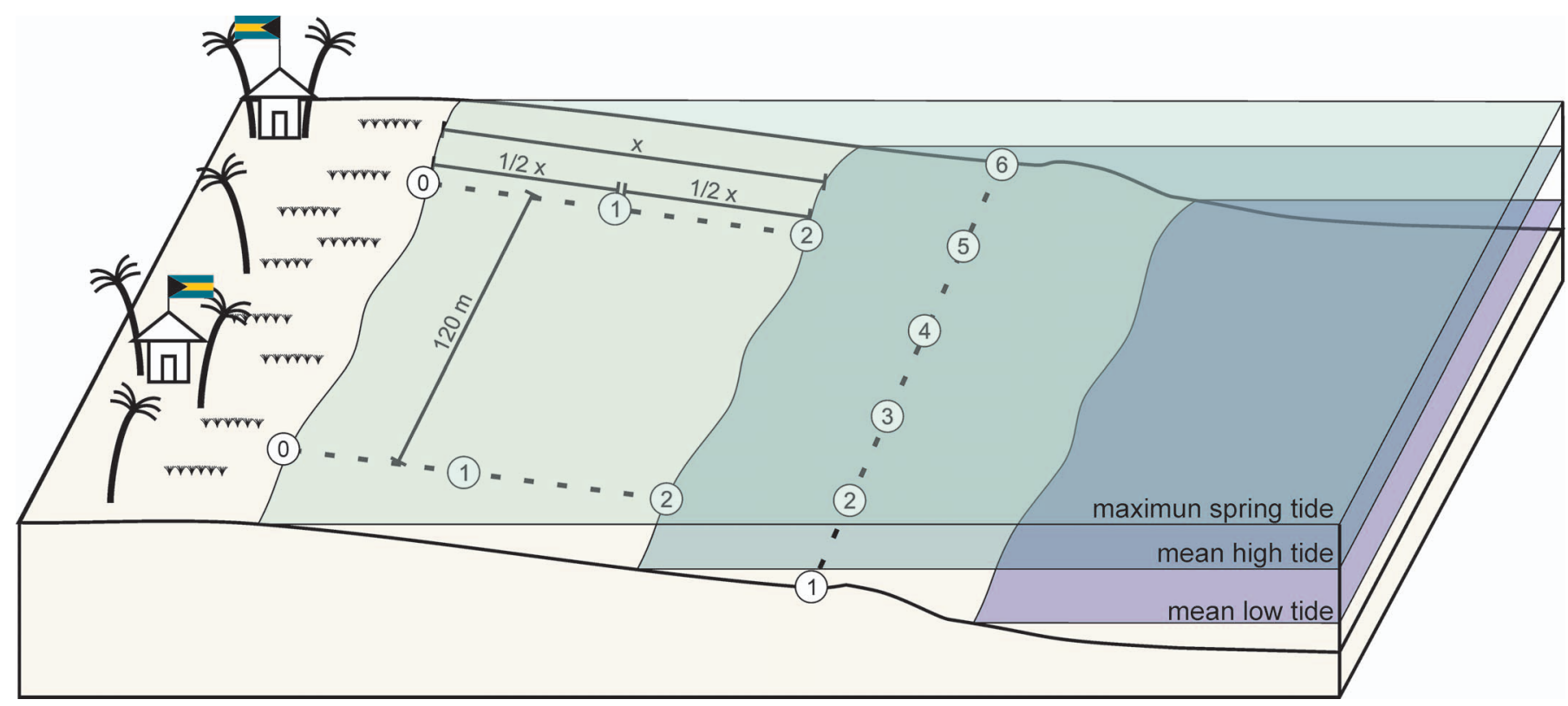

FIG. 3.- Scheme showing the sampling method, which consisted of three transects per locality. Two equidistant transects perpendicular to the shore (120 meters distant) with three equidistant samples each one (sample 0 at maximum spring tide, sample 2 at mean high tide, and sample 1 equidistant between sample 0 and sample 2 ). A third transect was carried out in the intertidal zone and composed of six equidistant samples. Numbers correspond to samples. Each sample was collected by hand from $1 \mathrm{~m}^{2}$ surface quadrats.

\section{Data}

Samples were sieved and the fraction greater than $2 \mathrm{~mm}$ was retained (Kidwell 2002; Kowalewski and Hoffmeister 2003). Twenty-seven samples did not contain bioclast material, and a total of 57 samples were thus analyzed. Bivalved mollusk shells were picked from the remaining fraction and identified to species level (using Abbott 1974; Gosner 1999). The four most abundant species were selected for analyses: Americardia guppyi, Tucetona pectinata, Divalinga quadrisulcata, and Chione cancellata. Only complete shells and shell fragments with hinge were counted in each sample as one specimen accounting for a total of 4,497 shells. The taphonomic index for each species was calculated by coding approximately 50 shells of the given species ( 50 shells of the same species from the same sample). If there were a large number of shells of the species within the sample, 50 shells were randomly chosen for the taphonomic analysis. A total of 3,301 valves were scored for each of the taphonomic attributes (Online Supplemental File 1). The mean taphonomic score of each attribute per sample was calculated by weighing each species' mean attribute score in the sample by its relative abundance. The full data set consisting of 57 samples and 4,497 shells is termed the complete data set. This data set was further restricted in two different ways. First, one dataset was restricted to samples with more than 20 individuals, regardless of their composition. This dataset is termed as restricted dataset 1 and contained a total of 38 samples and 4,291 individual shells. Second, a culled dataset was restricted to samples where the four species were present; and each species was represented by at least of five shells. This dataset is termed as the restricted dataset 2 and consisted of 11 samples and 2,611 individual shells.

\section{Taphonomic Scoring}

To quantify the extent of damage and modification, ten taphonomic variables were measured on individual valves with binary scoring (Kowalewski et al. 1994; Kidwell et al. 2001) under a stereoscopic microscope $(6.3 \times)$. Zero corresponds to a low-impacted or pristine state while one corresponds to an altered state. A sample-level index of preservation is represented by the proportion of altered specimens relative to the total number of all specimens.

Fragmentation was coded as not fragmented (0) or fragmented (1), using valves with broken edges or at least $30 \%$ of valve preserved (1). Abrasion was coded as original ornamentation (0) or abraded (1) when superficial ornamentation was lost or surface shell layers were exposed. Hinge preservation was coded as well preserved hinge teeth (0) or poorly preserved, with broken or abraded hinge teeth (1). Preservation of muscle scars was coded as well preserved scars (0) or poorly preserved, without any traces of scars preserved (1). Color alteration was scored as preserved original color ( 0$)$ or color loss (1). Color preservation is evident in $T$. pectinata, C. cancellata, and A. guppyi whereas it is more difficult to score in D. quadrisulcata. Nevertheless, this species has a glossy white shell as its original color, and ivory white when it lost its color (DeVictor et al. 2010; Witherington and Witherington 2011). Well preserved internal glossiness was coded as (0) while the loss of glossiness was coded as (1). A similar score was used for external glossiness. Other taphonomic attributes were coded as presence (1) or absence ( 0 ), namely external cementation, internal cementation, and biological encrustation (Figs. 4, 5).

\section{Analyses}

Extrinsic Variation in Preservation, Taphofacies Analyses.-The taphonomic preservation of assemblages is analyzed with respect to two environmental variables. First, intense wave action can induce high physical breakage and abrasion and low degrees of encrustation and bioerosion (Fürsich and Flessa 1987; Kidwell and Behrensmeyer 1988; Meldahl and Flessa 1990; Best and Kidwell 2000a). Thus we discriminate the windward sites from the leeward sites because San Salvador is influenced by easterly winds that produce progradation of many beaches (Gerace et al. 1998), and compare taphofacies between high-energy and low-energy localities. Second, we compare differences in preservation between sandy and rocky beaches because shells can be more frequently fragmented on hard-grounds or between rocks and pebbles and/or can be mixed with exhumed shells with different taphonomic signatures (Parsons 

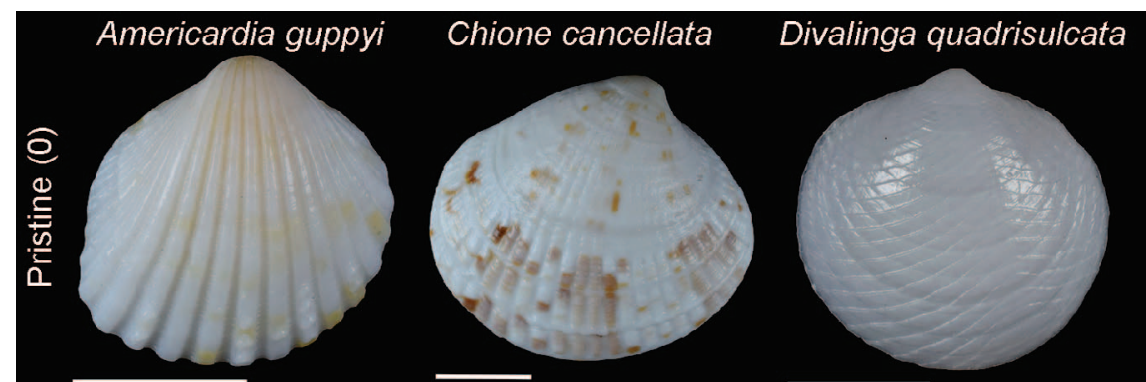

Tucetona pectinata
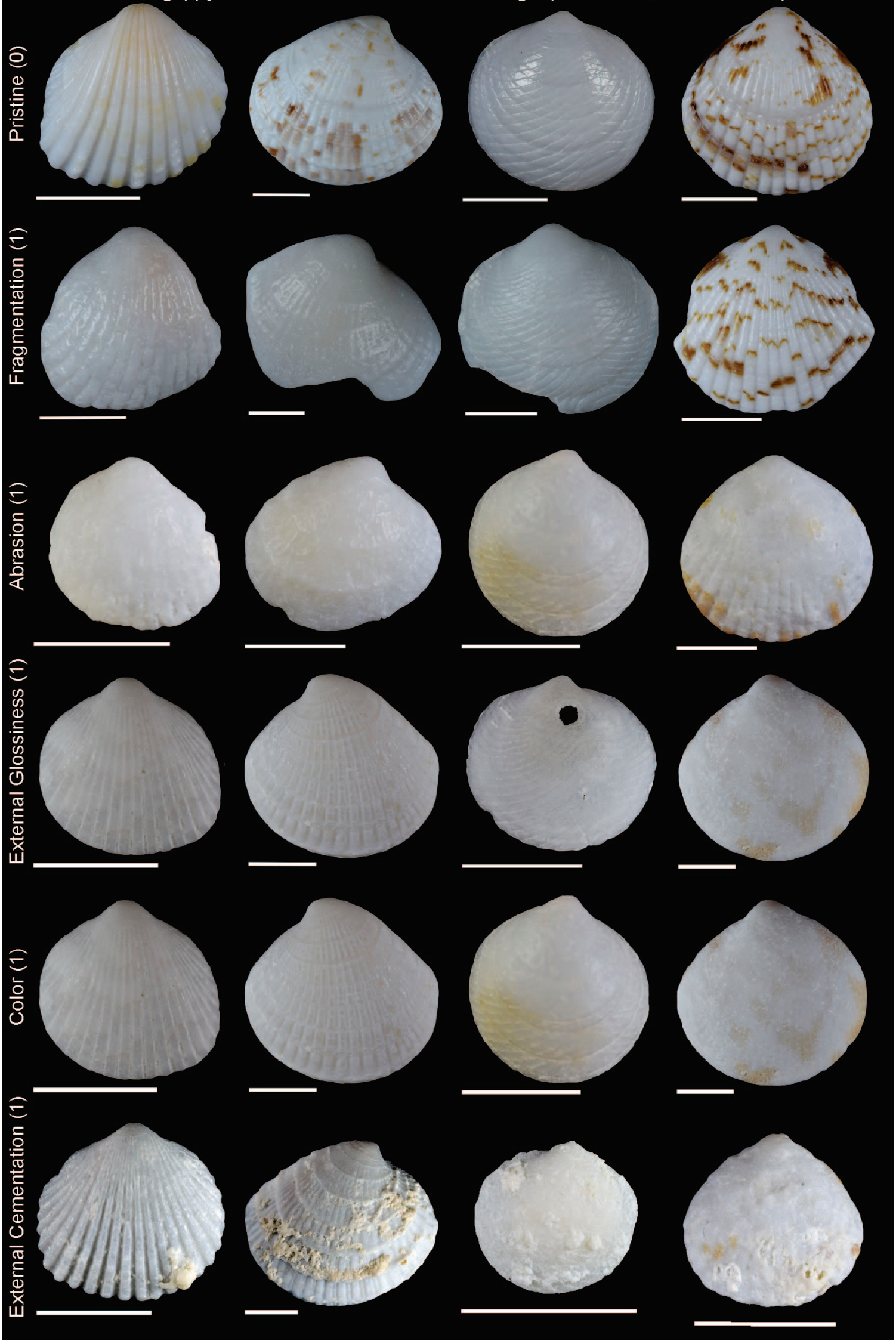

FIG. 4.-Examples of taphonomic variables measured in the external valve of the four selected species. Zero corresponds to a low-impacted or pristine state while one corresponds to an altered state. Scale bar $=1 \mathrm{~cm}$. 


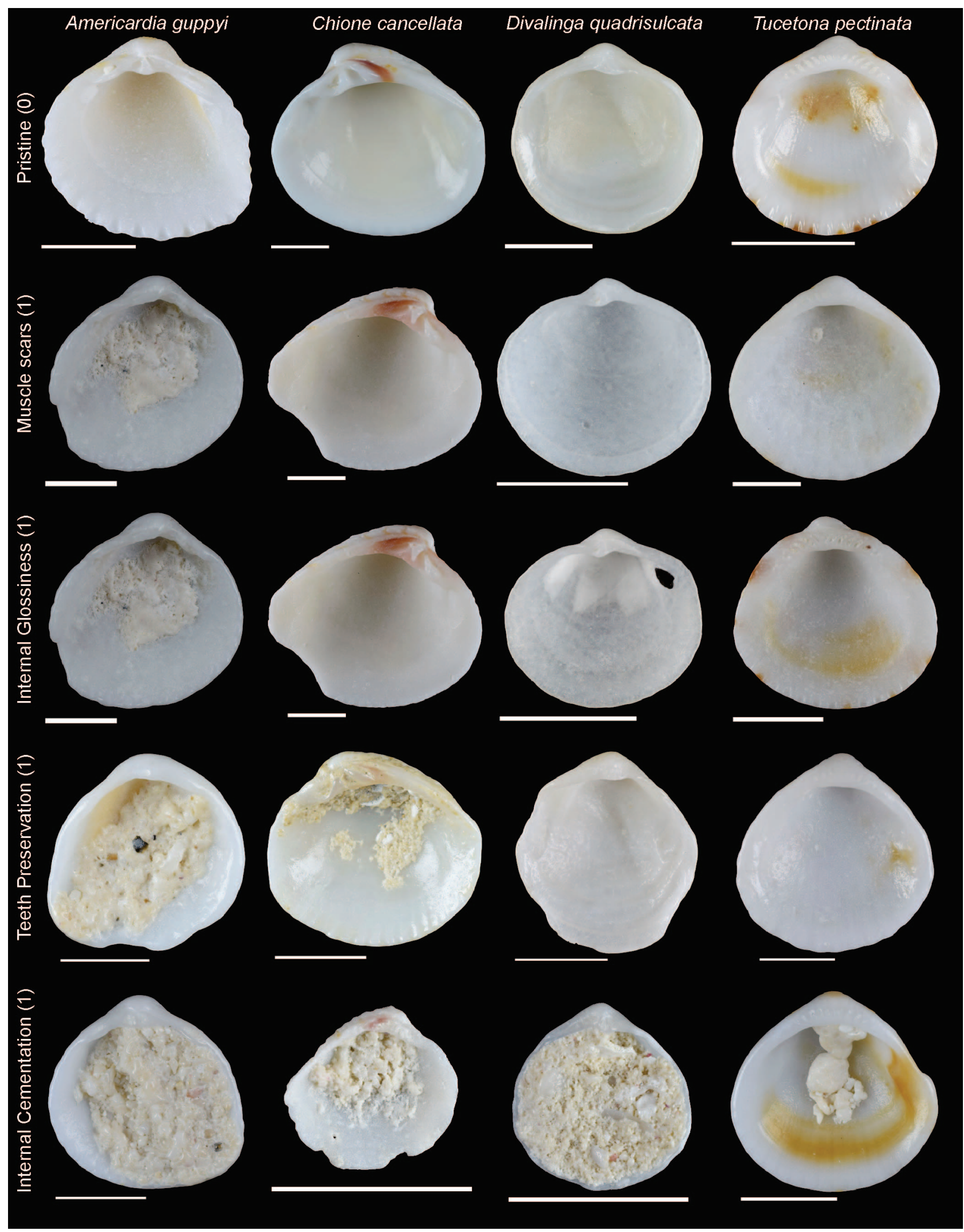

FIG. 5.-Examples of taphonomic variables measured in the internal valve of the four selected species. Zero corresponds to a low-impacted or pristine state while one corresponds to an altered state. Scale bar $=1 \mathrm{~cm}$. 
and Brett 1991; Best and Kidwell 2000a). San Salvador Island shows a variety of beaches, and their differences are based on the amount of beach rock patches (rocky), but some of them exhibit only beach sand (sandy) (Pruss et al. 2011).

To investigate the environmental control on assemblage profile based on ten taphonomic variables, we used a Principal Coordinate Analysis (PCoA) based on Manhattan distances (Legendre and Legendre 2012; Tomašových et al. 2017). For each variable in PCO, the vector direction indicates the direction of the trend in taphonomic alteration from pristine to highly altered. Vector length along each ordination axis indicates the correlation of the variable with the axis. The PCoA was carried out in R Software (CRAN, R Core Team 2015) using the pcoa() function in the ape package, while Manhattan distance was calculated using vegdist() in the vegan package. We used a Multivariate Analysis of Variance with Permutation (PERMANOVA) (Anderson 2001; Warton et al. 2012) to test for significant differences in preservation of bivalve assemblages between four environments. We carried out the PERMANOVA with 4999 permutations using the adonis() function in vegan package for $\mathrm{R}$.

Taphofacies Recognition Per Individual Species. - We analyzed each species separately to investigate the presence of intrinsic variation among taxa. The intrinsic signal was analyzed between and within four environments. First, we carried out a PCO based on taphonomic alteration for each species separately based on Manhattan distance, and used PERMANOVA with Bonferroni correction to test whether the four environments differ in preservation in each of the four species.

Second, following Best and Kidwell (2000b), we also analyzed whether the intensity of taphonomic attributes differed among the four taxa within each taphofacies and whether the rank order of taphonomic attributes in each environment was maintained among all taxa. Third, we analyzed the Spearman rank correlation of assemblage-level proportions of taphonomic variables between species, separately for all six pairwise between-species comparisons. Contrary to the two previous methods, this analysis was focused on the coherence of taphonomic patterns between two taxa in all samples where they co-occurred. These correlations were carried out on the complete dataset composed of samples with five or more individuals of at least two species. Because the number of samples differed between comparisons, we used Fisher's method for combining $p$ values to test for an overall correlation (Quinn and Keough 2002) and then compared correlation coefficients rather than plain $\mathrm{p}$ values. Fisher's method is calculated as $\chi^{2}=-2 * \Sigma \ln (\mathrm{P})$, where $\mathrm{P}$ is the probability of each correlation (i.e. the p-value). The statistic is distributed as a chi-square with degrees of freedom equal to double the number of $p$ values pooled.

Intrinsic Variation.-To test whether intrinsic differences among species generate distinct taphonomic signals, we performed a PCO and a PERMANOVA within each beach type by comparing taphonomic profiles of individual species. The analyses were performed within the three beach types where all four species were present.

Biofacies Analyses.- Relative abundance of each species was analyzed along the same environmental gradient as taphofacies (Online Supplemental File 2). To explore differences in composition and relative abundances among samples from different geographical settings and beach types, we used Principal Coordinate Analysis with Bray-Curtis distances

Comparison of Biofacies with Taphofacies.-Strong differences in relative abundances of species differing in their taphonomic response might change the taphonomic signature of death assemblages collected in similar environments. To test for this possibility, we first performed a Mantel test between the dissimilarity matrix based on species relative abundances and the dissimilarity matrix based on taphonomic attributes (i.e., taphofacies) to estimate the correlation between biofacies and taphofacies (Tomašových and Zuschin 2009). Second, we performed a Spearman rank correlation between sample scores along PCO axes based on relative abundances (biofacies) and taphonomic indices (taphofacies). Third, we carried out a Procrustes analysis between the two ordinations. We performed a Procrustes superimposition and tested the statistical significance of the correlation between ordinations with a Protest (PeresNetto and Jackson 2001). For these analyses we used only the first two axes of the ordinations, and 4999 permutations for the Protest. The Procrustes superimposition and Protest were carried out in R Software (CRAN, R Core Team 2015) using the procrustes() and protest() functions of the vegan package (Oksanen et al. 2016).

If biofacies and taphofacies do not correlate, one can assume that intrinsic factors do not control the taphonomic signature of the whole assemblage. However, if they do correlate, two scenarios are possible: (1) the same environmental factors that control both the composition and preservation of death assemblages or (2) relative abundances control the taphonomic signature of death assemblages correlated with each other. To differentiate between the two scenarios, we created two modified datasets. In the first dataset, we calculated the taphonomic index of each attribute in each sample by not weighing each species index by its relative abundance, i.e., simulating the scenario where all species had equal abundances. In the second dataset, we calculated the taphonomic index of each attribute in each sample by weighing each species index by an inverted relative abundance. The inverted relative abundance was performed in order to exacerbate the differences of the taphonomic profiles of these four species when their relative abundance varied. For this modified abundance test, we inverted the ranks of the species in each sample, i.e., the most abundant species had the abundance of the rarest one, and so on.

As a result, there were three matrices (datasets): the original one of taphonomic attributes based on the true relative abundance distribution, a simulated one based on equal relative abundance in all taxa, and a second simulated one based on the inverted distribution of relative abundances. We performed a Mantel test between the original dataset and the simulated ones to test whether or not the differences in relative abundances could cause significant bias. Mantel tests were carried out based on Spearman rank correlation.

Finally, we measured the shell length of the four species in order to qualitative evaluate if shell size affects the taphonomic profile between taphofacies. We constructed boxplots with shell length for each taphofacies.

\section{RESULTS}

\section{Taphofacies Analyses}

Four beach environments based on the preservation of all species can be identified on the basis of PCO, both with the complete data set and the restricted data set 1 ( $>20$ ind.). Sandy beaches show low and rocky beaches show high PCO1 scores (Fig. 6). High scores along PCO1 $(>21 \%$ of total variance) are driven mainly by lower external glossiness, higher external cementation and lower internal cementation in rocky relative to sandy beaches (Online Supplemental File 3 Table 3A). Rocky beaches record a higher mean alteration profile, while sandy beaches record a more variable one (Fig. 7). High and low-energy beaches are segregated along the $\mathrm{PCO} 2(>11 \%$ of total variance). Segregation along PCO2 (Online Supplemental File 3 Table $3 \mathrm{~A}$ ) is mainly controlled by higher fragmentation, poorer hinge-teeth, and lack of external glossiness in lowenergy sandy beaches (Fig. 7). The high-energy sandy taphofacies show remarkably low fragmentation $(0.37)$ in comparison to the other three taphofacies (between 0.64 and 0.76; Fig. 7). The high-energy and lowenergy sandy beaches are segregated in PCO, the segregation is not so 

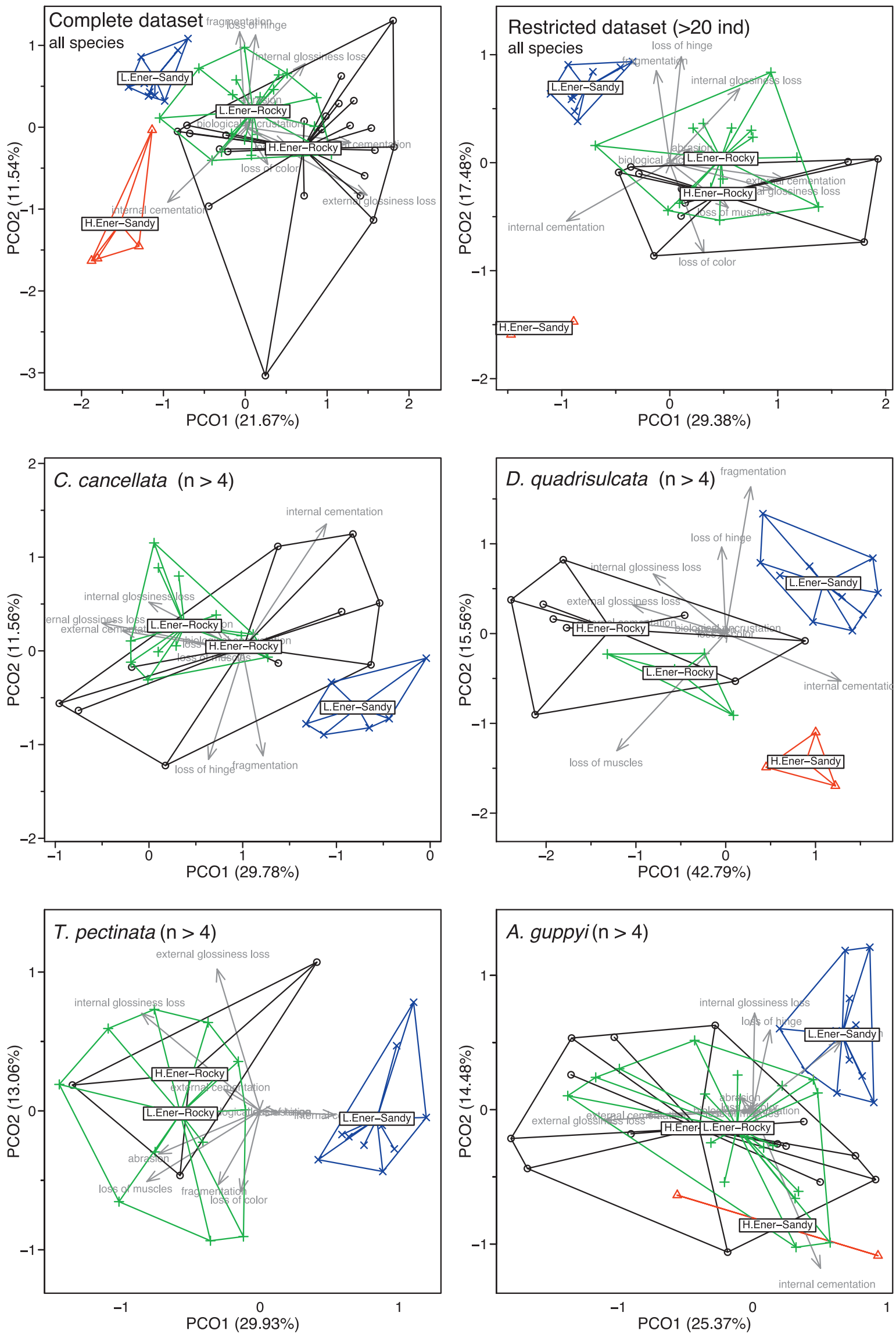

FIG. 6.-Principal Coordinate Analysis based on Manhattan distances exploring relationships among samples in terms of their preservation for the complete and the restricted dataset and for the four species, which were studied separately. 
TABLE 2.-Results of pairwise PERMANOVA between taphofacies. Boldface indicates significant $p$ values based on sequential Bonferroni correction.

\begin{tabular}{lllll}
\hline \hline & $\begin{array}{c}\text { High-energy } \\
\text { sandy }\end{array}$ & $\begin{array}{c}\text { Low-energy } \\
\text { sandy }\end{array}$ & $\begin{array}{c}\text { High-energy } \\
\text { rocky }\end{array}$ & $\begin{array}{c}\text { Low-energy } \\
\text { rocky }\end{array}$ \\
\hline High-energy sandy & \multicolumn{1}{c}{-} & & & \\
Low-energy sandy & d.f. $=1,13$ & - & & \\
& $\mathrm{F}=14.72$ & & & \\
& $\mathrm{p}=\mathbf{0 . 0 0 1}$ & & & \\
High-energy rocky & d.f.=1,25 & d.f. $=1,32$ & - & \\
& $\mathrm{F}=9$ & $\mathrm{~F}=16.25$ & & - \\
Low-energy rocky & $\mathrm{p}<\mathbf{0 . 0 0 1}$ & $\mathrm{p}<\mathbf{0 . 0 0 1}$ & & \\
& d.f.=1,23 & d.f. $=1,30$ & d.f. $=1,42$ & - \\
& $\mathrm{F}=14.54$ & $\mathrm{~F}=16.71$ & $\mathrm{~F}=5.05$ & \\
& $\mathrm{p}<\mathbf{0 . 0 0 1}$ & $\mathrm{p}<\mathbf{0 . 0 0 1}$ & $\mathrm{p}<\mathbf{0 . 0 0 1}$ & \\
\hline
\end{tabular}

evident for rocky beaches (Fig. 6). However, PERMANOVA indicates that low-energy and high-energy rocky beaches were actually segregated in the multivariate space (Table 2). The segregation between high-energy and low-energy rocky beaches is controlled almost exclusively by external glossiness of shells, with high-energy rocky beaches showing higher alteration (Fig. 7).

\section{Taphofacies Recognition Per Individual Species}

Multivariate Analysis by Individual Species.-PCO based on taphonomic alteration for each species separately (Fig. 6) shows that although the low-energy sandy taphofacies is clearly differentiated in all four species (Fig. 6; Online Supplemental File 3 Table 3B), the remaining beach types do not always show distinct signatures. The low- and highenergy taphofacies invariably overlap in the ordination space in all four species (Fig. 6). Nevertheless, these taphofacies differ in T. pectinata (Online Supplemental File 3 Table 3B). Finally, the high-energy sandy taphofacies is differentiated in the ordination space based on the $D$. quadrisulcata assemblage, and overlaps with the high- and low-energy rocky taphofacies the A. guppyi assemblage. Nevertheless, the high-energy sandy taphofacies significantly differs from all others based on $A$. guppyi or D. quadrisulcata preservation (Online Supplemental File 3 Table 3B). The only exception is that the high-energy sandy taphofacies is only marginally different from the low-energy rocky taphofacies on the basis of
TABLE 3.-Results of PERMANOVA between species taphonomic alteration within taphofacies. Boldface indicates significant $p$ values.

\begin{tabular}{lcc}
\hline \hline Low-energy sandy & High-energy rocky & Low-energy rocky \\
\hline d.f. $=1,33$ & d.f $=3,32$ & d.f. $=3,42$ \\
$\mathrm{~F}=31.05$ & $\mathrm{~F}=2.76$ & $\mathrm{~F}=12.64$ \\
$\mathrm{p}<\mathbf{0 . 0 0 1}$ & $\mathrm{p}<\mathbf{0 . 0 0 1}$ & $\mathrm{p}<\mathbf{0 . 0 0 1}$ \\
\hline
\end{tabular}

D. quadrisulcata assemblages (Online Supplemental File 3 Table 3B). Therefore, environments with the mixture of sands and beach rock are characterized by higher frequency of external cementation and abrasion than sandy beaches. Shells from low-energy beaches are more fragmented and discolored than shells from high-energy beaches.

Low-Energy Rocky Taphofacies. - In low-energy beach rock environments, C. cancellata, A. guppyi, and D. quadrisulcata exhibit consistently high alteration $(>0.4)$ on the basis of most variables, with particularly high fragmentation, poor muscle scar, and poor color preservation (Fig. 8). Chione cancellata shows the highest alteration profile, and D. quadrisulcata records relatively high internal and low external cementation, and significantly better preservation of hinge teeth (Fig. 8). Tucetona pectinata shows more variable responses, also having high fragmentation and poor muscle scar preservation, but much lower loss of color (Fig. 8). The external side was significantly better preserved than the internal side in $T$. pectinata with higher glossiness and smaller cementation (Fig. 8).

High-Energy Rocky Taphofacies.-Four species in this taphofacies also recorded similar taphonomic profiles, with high alteration in $A$. guppyi, C. cancellata, and D. quadrisulcata, and a different profile in $T$. pectinata. The three species with similar profiles show consistently high fragmentation, and poor color, muscle scars and teeth preservation (Fig. 8). All three species also show similar levels of internal and external glossiness and cementation. As in low-energy rocky taphofacies, $T$. pectinata had much higher color preservation and lower outer surface alteration, with high glossiness preservation and smaller cementation.

Low-Energy Sandy Taphofacies.-This taphofacies recorded much higher intrinsic variation than both beach rock taphofacies (Fig. 8). Americardia guppyi and C. cancellata share very high fragmentation and

Taphonomic profiles
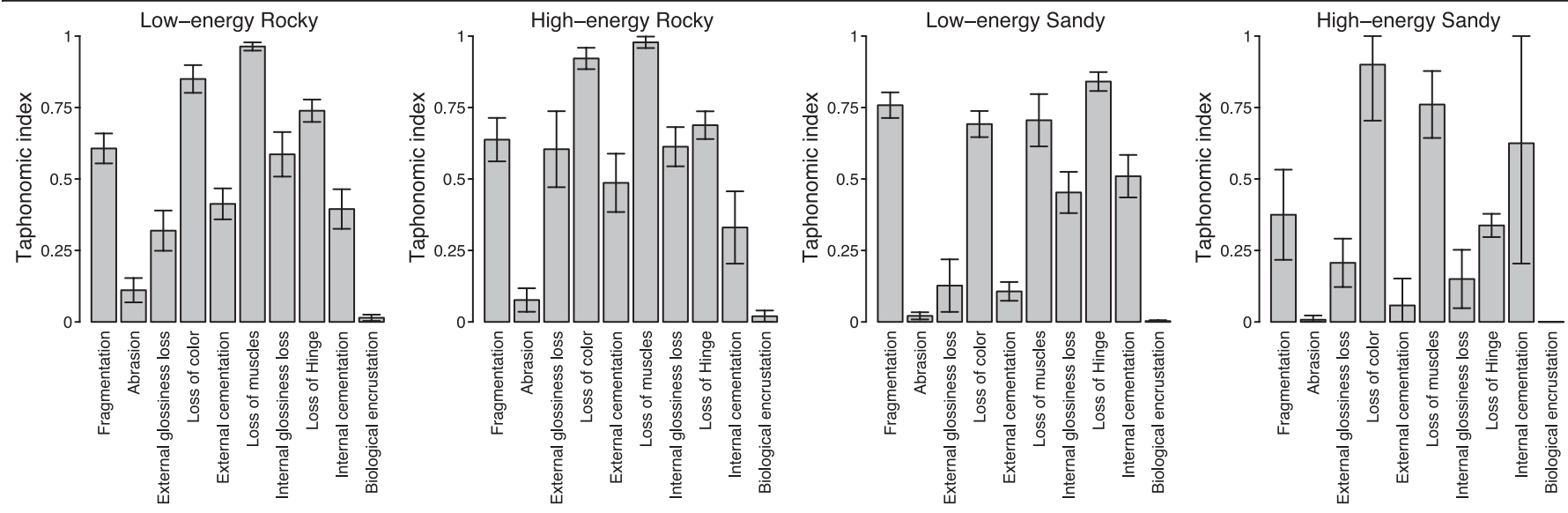

FIG. 7. - Bar plots showing taphonomic profiles of the four defined taphofacies for the complete dataset. Whiskers represent a $95 \%$ confidence interval. 


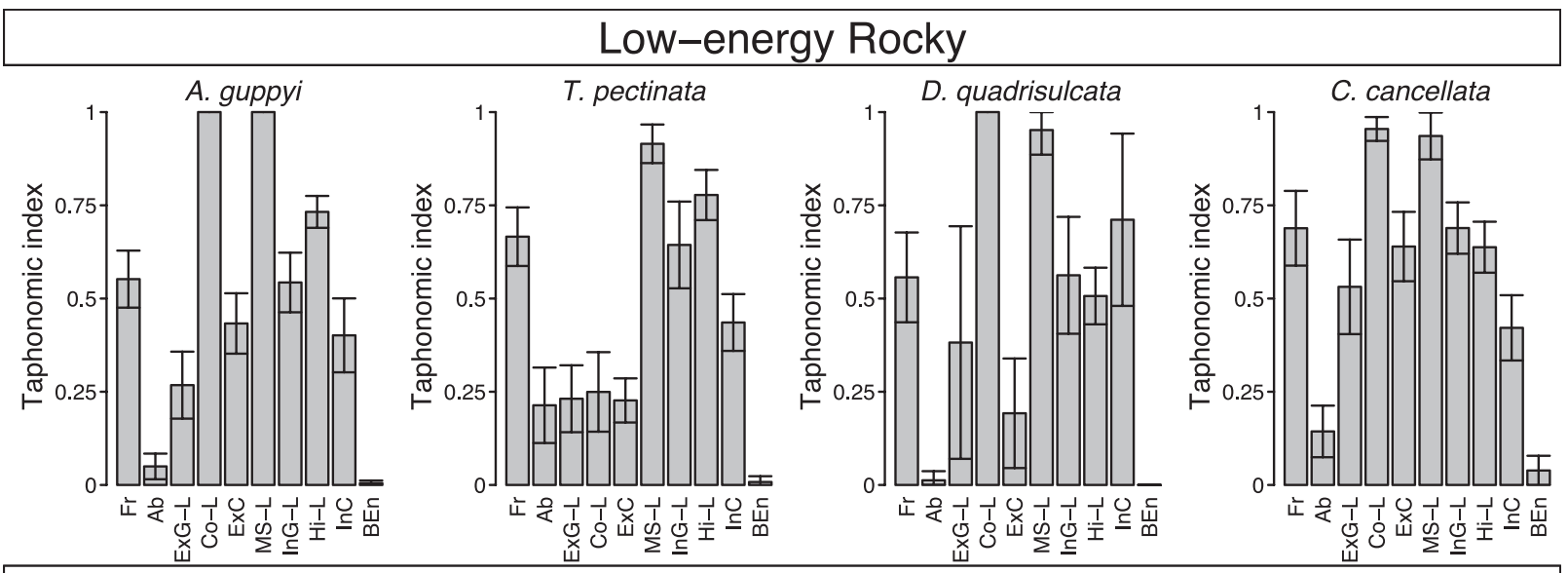

High-energy Rocky
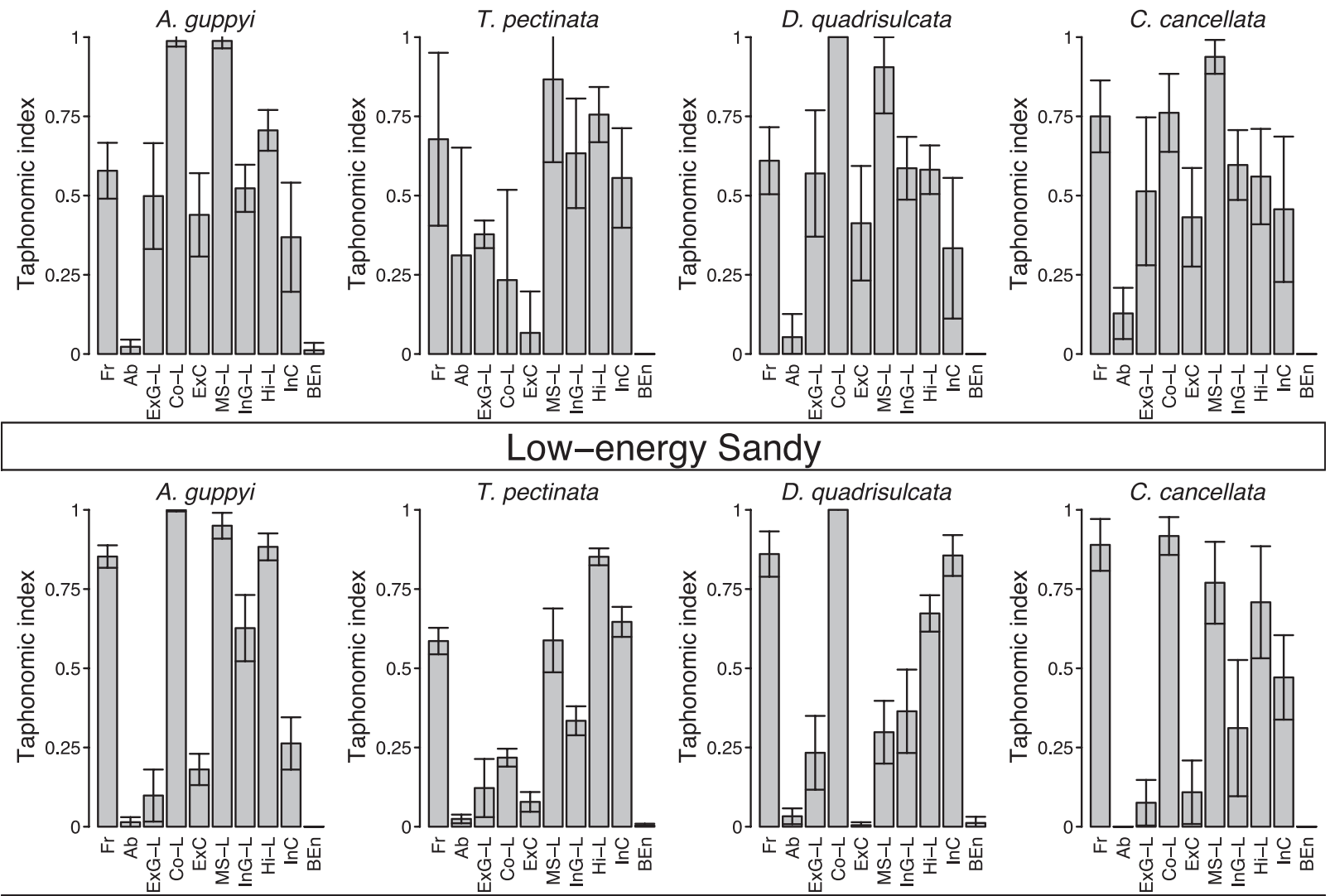

\section{High-energy Sandy}
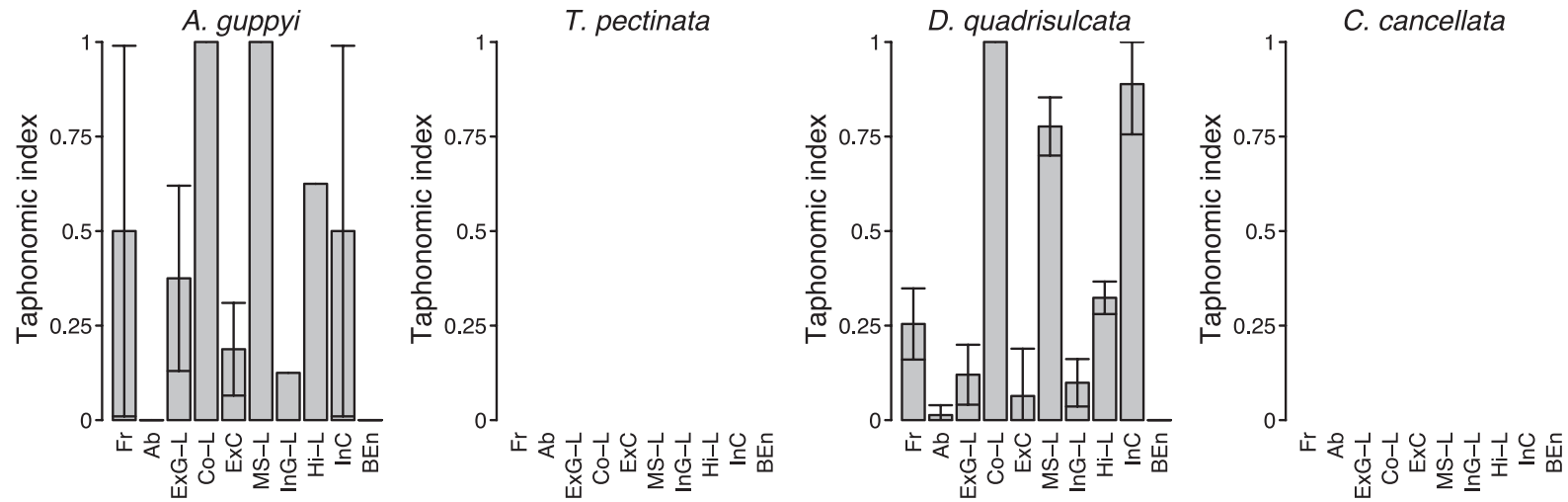

FIG. 8.-Bar plots showing taphonomic profiles of the four species in each taphofacies where they are present. Whiskers represent a 95\% confidence interval. Abbreviations: Taphonomic index $=$ proportion of altered valves; $\mathrm{Fr}=$ fragmentation; $\mathrm{Ab}=$ abrasion; Co $=$ color preservation; $\mathrm{MS}=$ muscle scars; Te $=$ hinge teeth preservation; ExGl = external glossiness; $\mathrm{InGl}=$ internal glossiness; ExC $=$ external cementation; InC $=$ internal cementation; $\mathrm{BEn}=$ biological encrustation. 
poor preservation of color, muscle scars, and teeth preservation. However, A. guppyi shows lower internal glossiness preservation while $C$. cancellata shows higher internal cementation. In contrast to A. guppyi and $C$. cancellata, D. quadrisulcata shows better preservation of muscle scars and higher internal cementation but almost no external cementation. Tucetona pectinata shows a variable degradation profile where color was better preserved than in the other three species. The external surface shows better preservation than the internal surface, especially with regard to original glossiness and cementation.

High-Energy Sandy Taphofacies.-Americardia guppyi and $D$. quadrisulcata possess similar preservation profiles, with high internal cementation and low fragmentation relative to the other three taphofacies. Americardia guppyi exhibits a higher deterioration profile than $D$. quadrisulcata, with higher fragmentation, lower preservation of muscle scars and teeth, lower external glossiness, and lower internal cementation (Fig. 8).

Intrinsic Variation.-Our analysis of intrinsic differences among species within taphofacies underscores that taxa show significant differences in alteration within each taphofacies (Table 3). Tucetona pectinata exhibited the greatest intrinsic differences in taphonomic response, as it differs from other species within all studied taphofacies (Online Supplemental File 3 Table 3C). The other three species, however, also show significant differences between them within the low-energy rocky and low-energy sandy taphofacies (Online Supplemental File 3 Table 3C). These results indicate that regardless of the particular environmental setting, there is always at least one species that shows significant differences, and in most cases all species respond differently.

Regardless of such intrinsic differences in taphonomic response among species, all show similar preservation trends along environmental gradients. Mantel tests show that between-species taphonomic profiles are significantly positively correlated among samples (pooled p-value, $X^{2}=$ 92.47, $\mathrm{df}=12, \mathrm{p}<0.0001)$ (Online Supplemental File 3 Table 3C).

\section{Biofacies and Compositional Differences}

High-energy and low-energy beaches, as well as sandy and rocky beaches, significantly differ in species composition (Fig. 9). This difference is clearer in the restricted dataset and blurred in the complete dataset owing to small sample size of some assemblages (PERMANOVA; Table 4; Fig. 9). Rocky beaches were clearly dominated by A. guppyi, which accounted for more than $50 \%$ of individuals (Fig. 10). However, low-energy and high-energy beach rock environments differ in the relative abundance of the other species. Tucetona pectinata was the second most abundant species and D. quadrisulcata was the rarest one in lower energy rocky beaches (Fig. 10), while the opposite pattern occurred in higher energy rocky beaches (Fig. 10). Low-energy sandy beaches were characterized by the dominance of A. guppyi, but also by the high abundance of $T$. pectinata and the very low abundance of $C$. cancellata (Fig. 10). Finally, high-energy sandy beaches were dominated by $D$. quadrisulcata, but were also characterized by the absence of $T$. pectinata and C. cancellata (Fig. 10).

\section{Taphofacies and Relative Abundances}

Different results indicate that species relative abundances coincide with the mean taphonomic response of each sample. First, the Mantel test shows that distances between samples based on taphonomic alteration values and species relative abundances are correlated (Spearman $\rho=0.4779$, $p$ $<0.0001$ ). Second, a simple visual comparison between biofacies and taphofacies PCOs (Figs. 6, 9) suggests that ordinations are rotated $90^{\circ}$ relative to each other. The PCO 1 axis based on taphonomic indices thus best corresponds to the PCO 2 axis based on species relative abundances. Therefore, maximum variance in species abundance is rather orthogonal to maximum variance in taphonomic information. The Spearman rank correlation test between biofacies PCO 2 and taphofacies PCO 1 site scores, is positive (Fig. 11; Spearman $\rho=0.602, p<0.0001$ ). Third, the Procrustes superimposition and Protest further confirm that the ordinations are significantly correlated (Online Supplemental File 3 Fig. 3D). Taphonomic profiles of the four taphofacies did not differ in our simple simulation used to explore the role of taxonomic control over the taphonomic signature, either based on equal or inverse abundances (Fig. 12). Only low-energy sandy taphofacies showed some differences between the original taphonomic profile and the one based on modified abundances. Differences, however, were concentrated in a few taphonomic attributes, such as color preservation and internal cementation, which showed higher alteration in the equal and inverse abundance cases. There were some minor differences between original and modified abundances in the other three taphofacies, but taphonomic profiles were not qualitatively modified (Fig. 12). Moreover, Mantel tests showed that taphonomic profiles based on original and modified abundances were correlated in all four taphofacies (Table 5), confirming that the minor differences that can be observed (Fig. 12) are not statistically significant.

Finally, to detect whether shell size affects the taphonomic profile, we compared the shell length of the four species between taphofacies (Online Supplemental File 4). We found that shell size does not discriminate between the beach types, which are characterized only by differences in taphonomic damage (Online Supplemental File 1). Also, taphonomic damage showed no difference between species with different shell size. This indicates that the taphonomic response to the environmental gradient varies only in a qualitative way, even if species differ in shell size (Fig. 13).

\section{DISCUSSION}

Four beach taphofacies in San Salvador Island can be distinguished on the basis of differences in environmental energy (high- or low-energy) and substrate type (sandy or beach rock), differing in external cementation, fragmentation, hinge teeth preservation, and external glossiness. Therefore, the bivalve death assemblages detect an environmental signature induced by exposure to high-energy events and by differences in cementation rate (between beach rock and sandy beaches), which most likely generates differences in the availability and abundance of exhumed and cemented shells. However, species relative abundance also varies between these four environments, leading to a strong correlation between taphofacies and biofacies. Such correlation implies that there is a relationship between death assemblage composition and its mean preservation metrics.

The four bivalve species share many intrinsic durability characteristics that affect their preservation. They possess aragonitic shells with crossedlamellar microstructure and live as infauna in subtidal sands (Moore and Lopez 1969; Taylor et al. 1969; Popov 1986; Alexander and Dietl 2001). Moreover, differences in shell size are not related to the environmental gradients. However, $C$. cancellata and T. pectinata have thick shells (shell thickness is $\sim 1.24 \mathrm{~mm}$ in C. cancellata and $\sim 1.22 \mathrm{~mm}$ in $T$. pectinata) while D. quadrisulcata and A. guppyi have the most delicate and thin shells (shell thickness is $\sim 0.81 \mathrm{~mm}$ in D. quadrisulcata and $\sim 0.91 \mathrm{~mm}$ in A. guppyi), as also observed by Pruss et al. (2011). Despite general similarities in shell structure and life habits, our results show intrinsic between-species differences in taphonomic response to environmental gradients. Given such differences and the correlation between species abundances and taphofacies, taphofacies differences among beach environments can be the result of differences in relative abundances and intrinsic taphonomic responses. However, Mantel tests show that taphonomic response was correlated between species whenever they cooccur (Online Supplemental File 3 Table 3E) and our simulations indicate that changes in relative abundances do not significantly modify the 

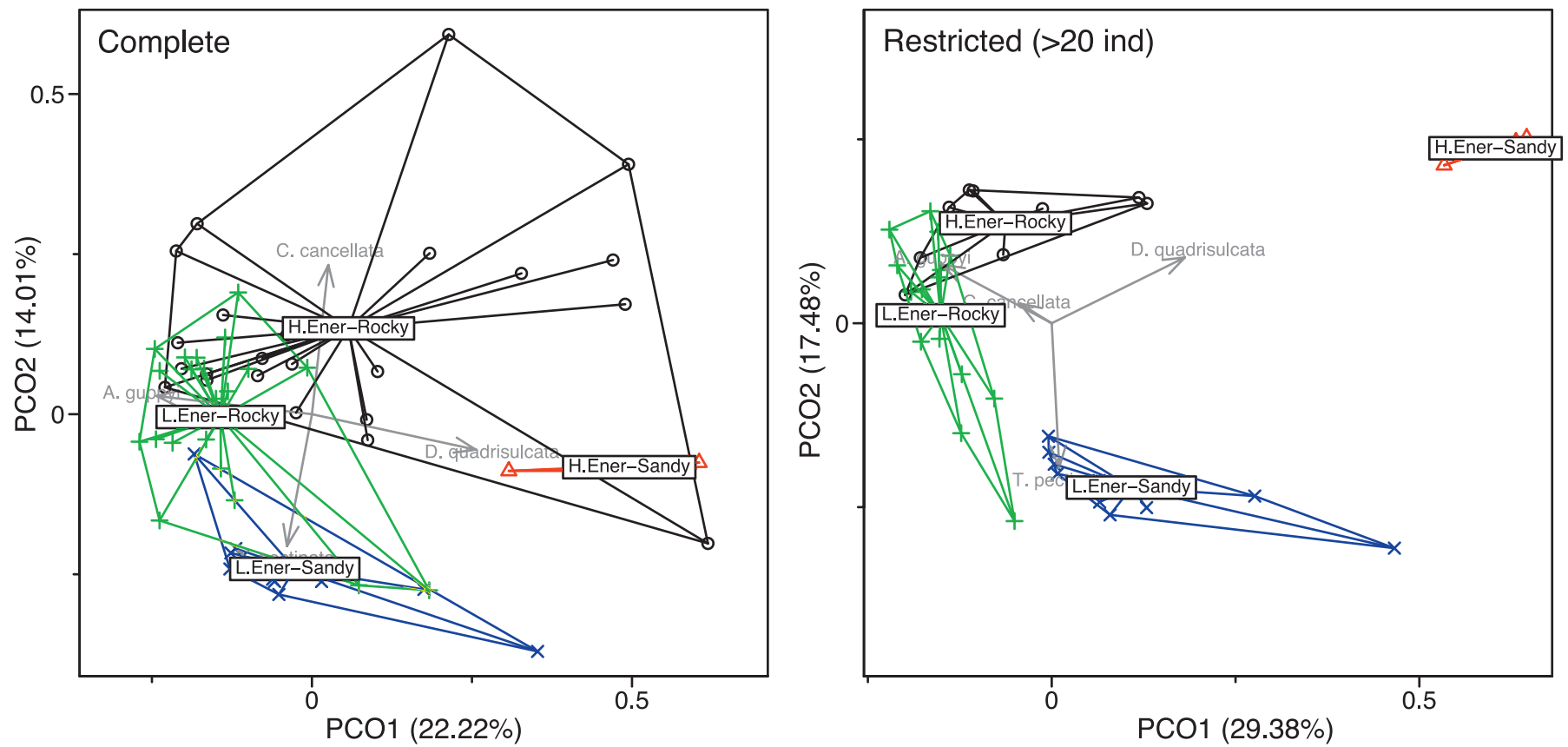

FIg. 9.-Principal Coordinate Analysis based on Bray-Curtis distances exploring differences in composition and relative abundances among samples from different geographical settings and beach types. A) PCO with complete dataset. B) PCO with restricted dataset.

taphonomic profile of each taphofacies. Therefore, intrinsic differences, are smaller than environmental differences, and are not strong enough to veil taphofacies recognition. Bivalve species thus share environmental gradients in taphonomic response as also found by other authors (Best and Kidwell 2000b; Kidwell 2001; Powell et al. 2002). This environmental sensitivity of bivalves agrees with results from other tropical environments (Best and Kidwell 2000a, 2000b), and underscores the findings that depositional environment is the dominant factor controlling the structure of taphofacies (scenario shown by Fig 1C). Differences in species relative abundances also do not bias the taphonomic profile of beach environments because they were not modified by altering relative abundances (Online Supplemental File 3 Table 3E, Fig. 3F). Such results underscore that intrinsic differences were small in relation to differences among taphofacies, which reinforces the usefulness of taphofacies for paleoenvironmental reconstructions (Tomašových and Zuschin 2009).

Molluscan death assemblages from high-energy beaches subjected to strong eastern trade winds (Brill 1993; Wright and Burchette 1996; Horwitz and Roberts 2010) should exhibit a high degree of physical

TABLE 4.-Results of pairwise PERMANOVA between biofacies. Boldface indicates significant $p$ values based on sequential Bonferroni correction.

\begin{tabular}{lllll}
\hline \hline & $\begin{array}{c}\text { High-energy } \\
\text { sandy }\end{array}$ & $\begin{array}{c}\text { Low-energy } \\
\text { sandy }\end{array}$ & $\begin{array}{c}\text { High-energy } \\
\text { rocky }\end{array}$ & $\begin{array}{c}\text { Low-energy } \\
\text { rocky }\end{array}$ \\
\hline High-energy sandy & \multicolumn{1}{c}{-} & & & \\
Low-energy sandy & d.f. $=1,13$ & - & & \\
& $\mathrm{F}=41.71$ & & & \\
High-energy rocky & $\mathrm{p}=\mathbf{0 . 0 0 1}$ & & & \\
& d.f. $=1,25$ & d.f. $=1,32$ & - & \\
& $\mathrm{F}=8.46$ & $\mathrm{~F}=13.27$ & & - \\
Low-energy rocky & $\mathrm{p}<\mathbf{0 . 0 0 1}$ & $\mathrm{p}<\mathbf{0 . 0 0 1}$ & & \\
& d.f. $=1,23$ & d.f. $=1,30$ & d.f. $=1,42$ & - \\
& $\mathrm{F}=42.85$ & $\mathrm{~F}=13.84$ & $\mathrm{~F}=8.96$ & \\
& $\mathrm{p}<\mathbf{0 . 0 0 1}$ & $\mathrm{p}<\mathbf{0 . 0 0 1}$ & $\mathrm{p}<\mathbf{0 . 0 0 1}$ & \\
\hline
\end{tabular}

alteration, especially high fragmentation and abrasion (Parsons-Hubbard 2005). However, death assemblages from high-energy sandy beaches only contain the most delicate species (A. guppyi and D. quadrisulcata) with a good preservation profile, including low fragmentation, well-preserved hinge teeth, and high glossiness. In contrast, the low-energy sandy beach (Sandy Point) shows higher fragmentation, poorer preservation of hinge teeth, and higher loss of internal glossiness in A. guppyi and D. quadrisulcata.

Pruss et al. (2011) found that the most abundant and robust shells- $T$. pectinata and C. cancellata-from the same low-energy sandy beach (Sandy Point) ranged in age from very young post-bomb specimens to specimens as old as $\sim 6,000$ years, thus showing extensive time-averaging. They inferred that some shells from this beach probably experience a complex history of burial and exhumation before their final deposition on the beach, suggesting that these shells must have been buried and rapidly lithified shortly after death (Friedman 1998; Pruss et al. 2011) and later exhumed. This lithification and exhumation process was described in a sandy beach by Nawrot (2012). Early cementation ensures that shells that are exhumed have longer taphonomic half-lives than shells without cementation. The combination of cementation and exhumation of shells thus significantly prolongs time-averaging (e.g., Tomašových et al. 2014). The intensity of cementation and exhumation probably varies on San Salvador beaches that exhibit different wave energy levels, sedimentation rates, beach profiles, and proportion of exposed beach rock and reworking of sand (Beavers et al. 1995; Voegeli et al. 2006; Pruss et al. 2011). Therefore, we hypothesize that the taphonomical pathway of sandy beaches from San Salvador is driven by a mixture of young shells living in intertidal and subtidal environments and older cemented shells exhumed from beach rock.

According to our results, assemblages from environments with the presence of beach rock show a high frequency of external cementation. Remarkably, young beach rock units in San Salvador are forming in the intertidal zone around the island (Beier 1985) and are filled with debris such as soda caps, broken glass, bits of steel, and other humanconsumption waste incrusted in the studied beach rock (Beier 1985; SB 


\section{Species relative abundance}
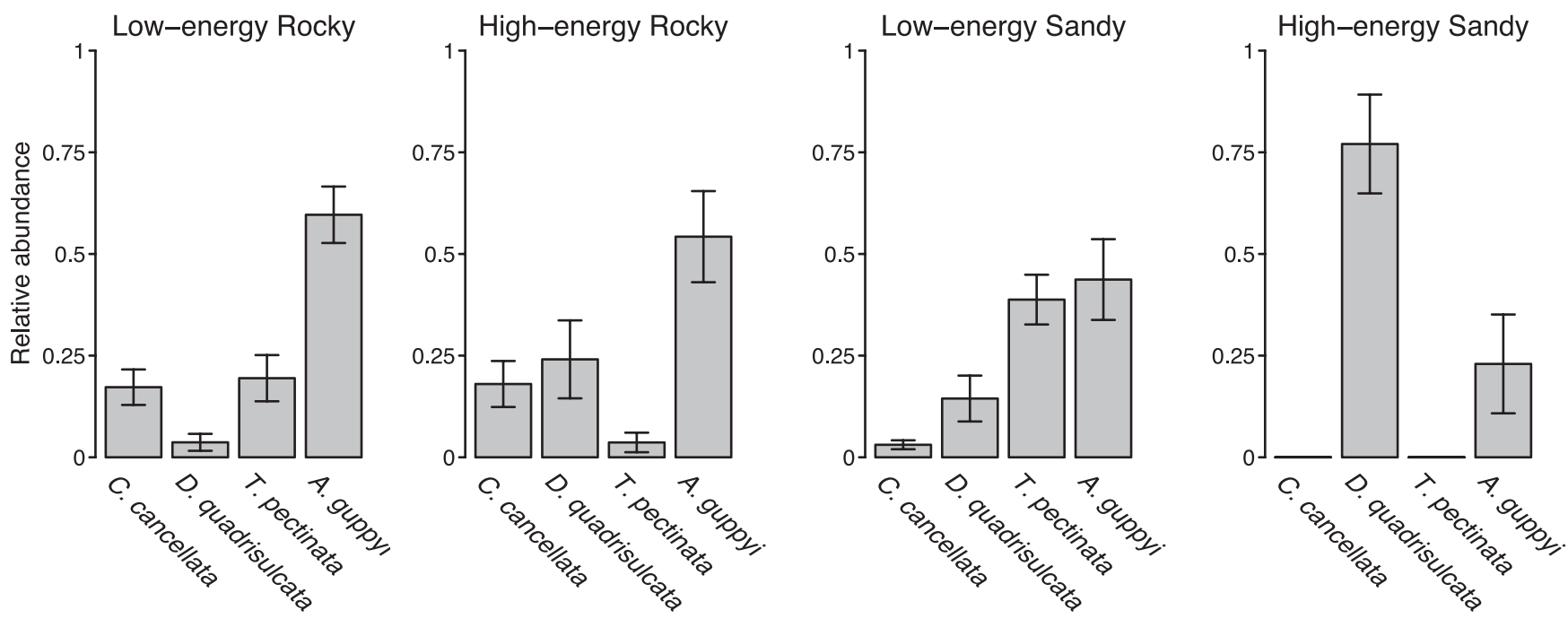

FIg. 10.-Bar plots showing relative abundances of the four species in each taphofacies where they are present. Whiskers represent a $95 \%$ confidence interval.

personal observation). These recent artifacts are cemented to the bottoms of the pits (Beier 1985), suggesting that these beach rocks are active and are characterized by a high cementation rate. Moreover, in beach rock beaches, Pruss et al. (2011) showed that out of eight dated shells, seven shells were decades to several centuries old whereas just one shell was 3,500 years old. This pattern suggests that death assemblages in beach rock environments are less time-averaged than death assemblages from sandy beaches. The taphonomical pathway of rocky beaches (beach rock environments) is probably driven by the high rate of cementation, where the available shells become part of the beach rock rapidly. Hence, valves spend in the taphonomically active zone shorter time as they cement

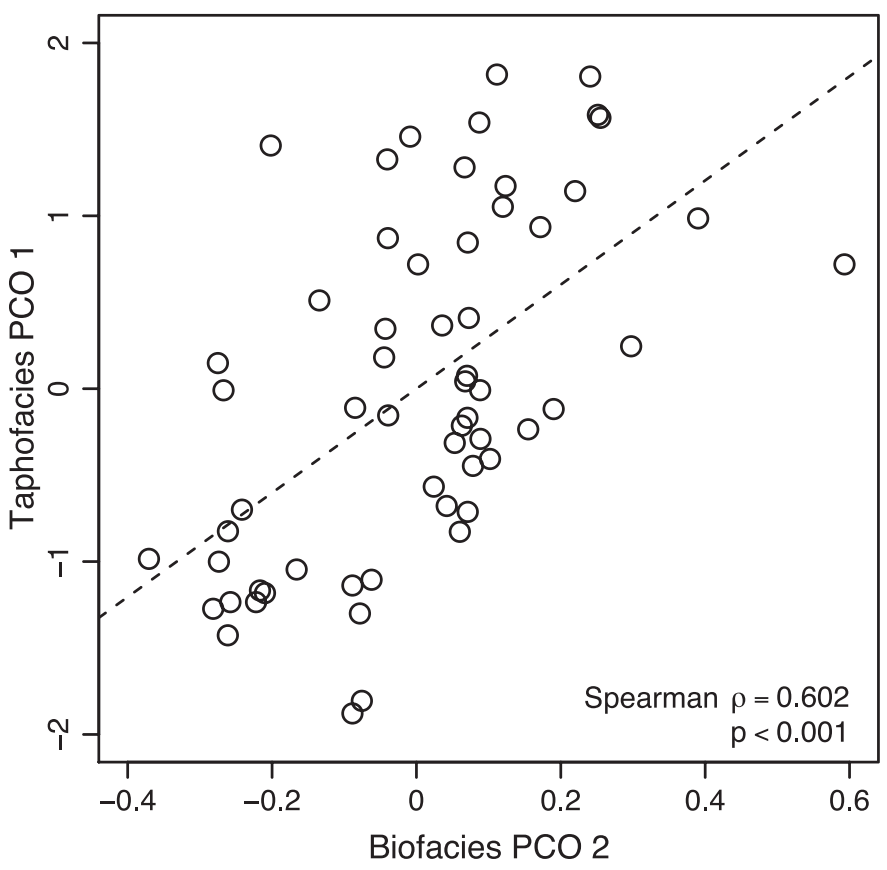

FIG. 11.- Spearman rank correlation between samples of biofacies PCO 2 and taphofacies PCO 1. Dash line corresponds to the linear regression. rapidly within the beach rock, reducing the time-averaging of the death assemblage.

Death assemblages on low-energy sandy beaches show poor preservation due to the mixture of young, well-preserved shells and old, highly altered shells. This coincides with the preservation profile of shell beds from a sandy beach characterized by molluscan assemblages from intertidal and shallow subtidal environments with fragmentation, abrasion, loss of luster and color (Nawrot 2012). At Sandy Point Beach, seasonal variation of beach profile frequently produces beach rock exposure (Loizeaux et al. 1993; Voegeli et al. 2006). It is possible that this stormbeach rock is the source of exhumed shells (Pruss et al. 2011). The highenergy sandy beaches, due to their higher environmental energy, record better-preserved shells because most of the shells are destroyed and the death assemblage is thus dominated by recently dead shells. Therefore, the frequency of older, resedimented valves is small.

This explanation invoking differences in the contribution of older shells permits a further interpretation of fidelity of death assemblages from San Salvador Island, at least for high-energy sandy beaches. Because lowenergy beaches are subjected to lower environmental energy, lower rates of shell destruction allow the mixture of old and young valves, and the death assemblage thus can be highly time-averaged (Kowalewski 1996; Kidwell 2013). Such assemblages will have lower fidelity to living assemblages than assemblages from high-energy beaches with a high rate of shell destruction (i.e., without input of older shells). This would imply that death assemblages from high-energy beaches should have a higher contribution of recently dead cohorts than low-energy sandy beaches (Kidwell 2002; Kowalewski et al. 2005). Hence, shells from low-energy beaches are more fragmented and discolored than shells from high-energy beaches. However, early cementation in tropical carbonate environments can enhance preservation potential of fragile shell, thus counteracting the effect of high time-averaging on live-dead compositional fidelity (Garcia-Ramos et al. 2016). On one hand, assemblages from sandy beaches are degraded at higher rate but are enriched by old exhumed and lithified shells. On the other hand, assemblages from beach rock environments are cemented at higher rate and become durable and thus more abraded. Therefore, the composition of biofacies in San Salvador Island seems to be modulated by a taphonomic sieve that, in low energy settings - and wherever there are 

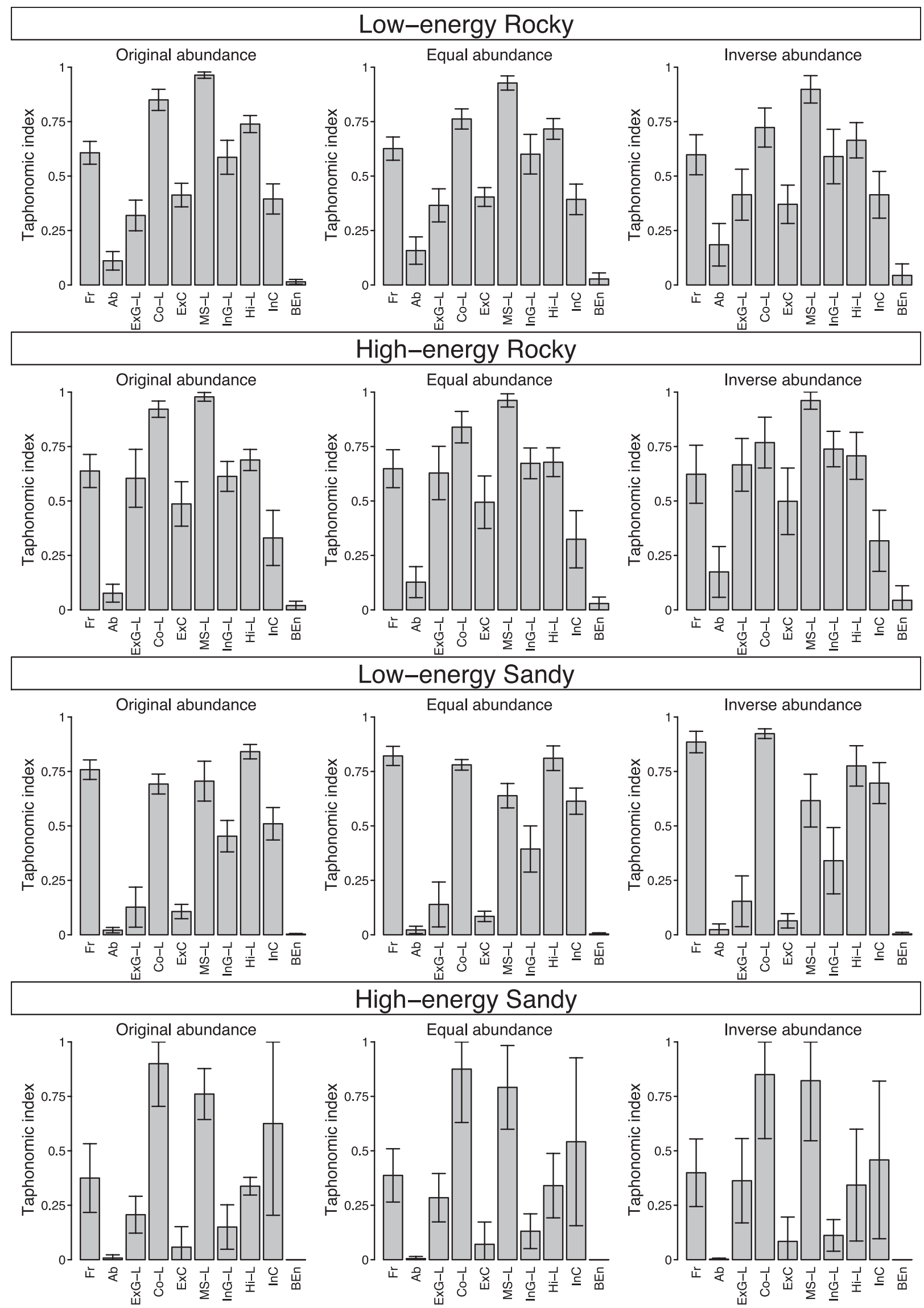

FIG. 12.-Bar plots showing taphonomic profiles of the four taphofacies according to taxa's relative abundances. Taphonomic profiles were weighed by species true relative abundances distribution, species equal relative abundances distribution, and species inverted relative abundances distribution. Whiskers represent a $95 \%$ confidence interval. Abbreviations explained in Figure 9. 
TABLE 5.-Pairwise Mantel test for mean taphonomic alteration at sample scale between original data and two modified abundances distributions. Spearman rank correlation coefficient are indicated in boldface and their corresponding $p$ values between brackets. Italics indicate significant $p$ values based on a sequential Bonferroni correction.

\begin{tabular}{|c|c|c|c|}
\hline & Original abundances & Equal abundances & $\begin{array}{c}\text { Inverse } \\
\text { abundances }\end{array}$ \\
\hline Original abundances & - & & \\
\hline Equal abundances & $\boldsymbol{\rho}=\mathbf{0 . 8 7 3}(p<0.001)$ & - & \\
\hline Inverse abundances & $\boldsymbol{\rho}=\mathbf{0 . 5 5 5}(p<0.001)$ & $\boldsymbol{\rho}=\mathbf{0 . 8 1 6}(p<0.001)$ & - \\
\hline
\end{tabular}

large beach rock patches-leads to an overrepresentation of old species with higher preservation potential but with higher damage profile.

Our results further show that strong differences in relative abundances do not veil the environmental taphonomic signature of the dead assemblage. However, contrasting taphonomic pathways for each environment could modify relative abundances, particularly by inflating timeaveraging in some environments. The correlation between taphonomic and compositional distances could indeed suggest that compositional differences between environments also generate taphonomic differences. However, if differences in relative abundances were a consequence of contrasting taphonomic pathways, then maximum change in taphonomic alteration should cause maximum compositional changes. In such cased, maximum variances along taphonomic and compositional gradients should be correlated. However, the gradient concentrating the maximum variance in species abundance (i.e., PCO1) does not coincide with the gradient of maximum variance in taphonomic alteration (Fig. 11). Therefore, the correlation is most probably caused by a common factor affecting biofacies and taphofacies, rather than a direct consequence of taphonomy over relative abundances. Hence, abundances are not biased by taphonomic pathways and the correlation between compositional changes and taphonomic alteration is probably caused by a common response of taphonomic and ecological processes to gradients in hydrodynamic levels, sedimentation rate, or substrate consistency (Tomašových and Zuschin 2009).

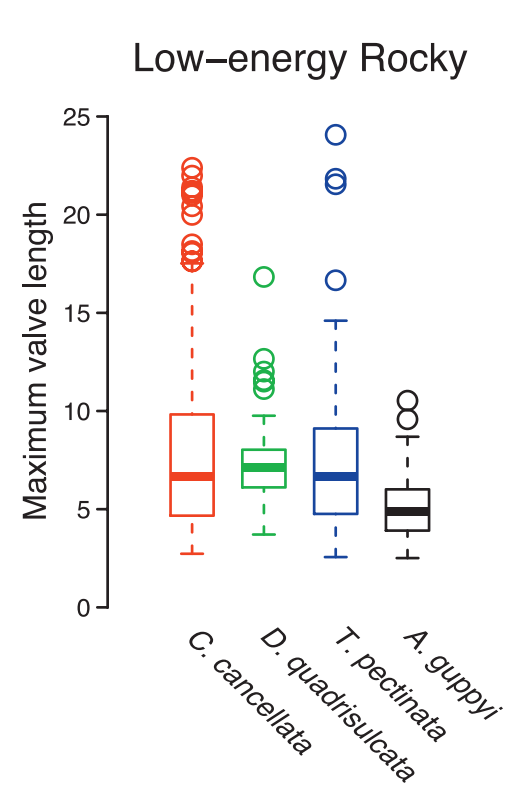

High-energy Rocky

○

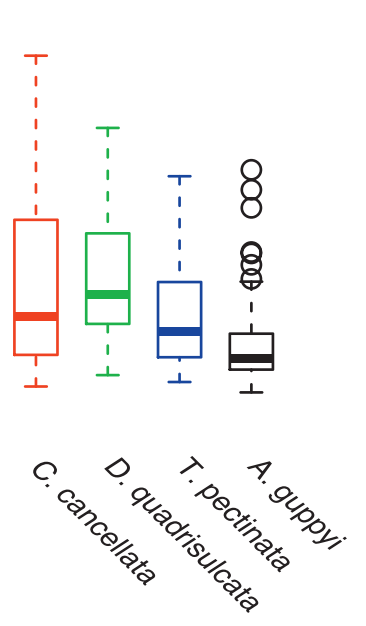

\section{CONCLUSIONS}

Carbonate beaches with bivalve death assemblages on San Salvador Island belong to four taphofacies based on shell preservation profile. They are discriminated on the basis of environmental energy (high vs. low energy) and beach features or sediment type (sandy vs. beach rock). Taphonomic profiles of shell assemblages from rocky beaches recorded a higher mean alteration than sandy beaches, and are characterized by shells with lower external and internal glossiness, more external cementation and poorer preservation of muscle scars. The four bivalve species differ in the magnitude of damage but still show similar trends in preservation along environmental gradients. The four species also differ in relative abundance along the environmental gradients; however, differences in abundance or in shell size do not bias the taphonomic profile of the four taphofacies. Highenergy sandy beaches in shallow carbonate environments, exposed to seasonal storms causing shell destruction, record better-preserved shells due to the dominance of young (recently dead) and thus well-preserved shell cohorts. In contrast, the taphonomical signal recorded in environments with the mixture of sands and beach rock is characterized by higher frequency of external cementation and abrasion but more durable than sandy beaches. On one hand, shells from sandy beaches are degraded at higher rate but are enriched by old exhumed and lithified shells. On the other hand, shells from low-energy beaches are more fragmented and discolored than shells from high-energy beaches. Depositional environment is the dominant factor controlling the structure of San Salvador taphofacies. Exposed beach rock patches probably represent the source of old, poorly preserved shells (Pruss et al. 2011; Nawrot 2012) that were mixed with recently dead cohorts of mollusks. Therefore, shell assemblages in low-energy carbonate beaches from San Salvador Island record higher time-averaging with higher damage profile due to the overrepresentation of old poor preserved shells.

\section{ACKNOWLEDGMENTS}

The study was conceived during the course "Taphonomy and Ecology of Terrestrial and Marine Environments" at the Gerace Research Centre, San Salvador Island, The Bahamas. SB thanks to T.A. Rothfus (Executive Director of GRC) and M. Kowalewski (University of Florida) for conducting the course and T. Dexter (University of Arizona), all TETME students, and the GRC staff for transportation, assistance in sampling, and productive discussions. SB also

\section{High-energy Sandy \\ Low-energy Sandy}
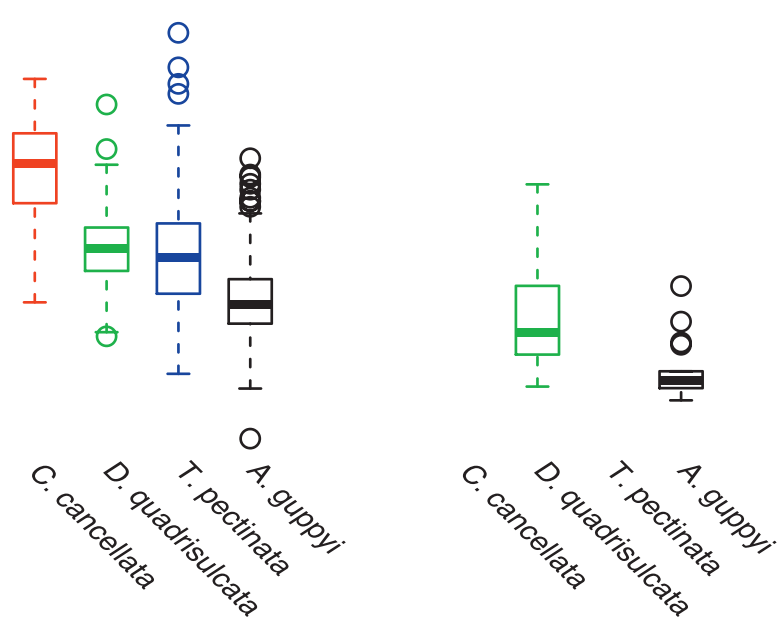

FIG. 13.-Shell size (length, $\mathrm{mm}$ ) of the four species between taphofacies. 
thanks to The Paleontological Society for providing a scholarship to partially offset the course expenses. We acknowledge Ivana Tapia (CICTERRA) for help with shells' photographs. We also acknowledge the anonymous reviewers as well as the Associate Editor for their rich and interesting contributions. The Gerace Research Centre (GRC-University of The Bahamas) and Centro de Investigaciones en Ciencias de la Tierra (CICTERRA), CONICET-Universidad Nacional de Córdoba for providing logistical facilities. Financial support for this study was provided by Agencia Nacional de Promocion Cientifica y Tecnologica (ANPCyT-FONCyT) PICT 2016-2951 awarded to S. Bayer. This is a contribution to PUE 2016 (CICTERRA - CONICET).

\section{SUPPLEMENTAL MATERIAL}

Data are available from the PALAIOS Data Archive:

http://www.sepm.org/pages.aspx?pageid=332.

\section{REFERENCES}

Аввотт, R.T., 1974, American Seashells, 2nd edition: Van Nostrand Reinhold Company, New York, $663 \mathrm{p}$.

Albano, P.G., Filippova, N., Steger, J., Kaufman, D.S., Tomašových, A., Stachowitsch, M., AND Zuschin, M., 2016, Oil platforms in the Persian (Arabian) Gulf: living and death assemblages reveal no effects: Continental Shelf Research, v. 121, p. 21-34, doi: 10.101 6/j.csr.2015.12.007

Alexander, R.R. And DietL, G.P., 2001, Shell repair frequencies in New Jersey bBivalves: a recent baseline for tests of escalation with Tertiary, Mid-Atlantic congeners: PALAIOS, v. 16, p. $354-371$.

Allmon, W.D., 1993, Age, environment and mode of deposition of the densely fossiliferous Pinecrest Sand (Pliocene of Florida): implications for the role of biological productivity in shell bed formation: PALAIOS, v. 8, p. 183, doi: 10.2307/3515171.

Anderson, M.J., 2001, A new method for non-parametric multivariate analysis of variance: Austral Ecology, v. 16, p. 32-46.

Beavers, R.L., Curran, H.A., And Fox, W.T., 1995, Long-term, storm dominated sediment dynamics on East Beach and Sandy Point, San Salvador Island, Bahamas, in M.R. Boardman (ed.), Proceedings of the 7th Symposium on the Geology of the Bahamas, San Salvador: Bahamian Field Station, p.1-15.

Behrensmeyer, A.K., Kidwell, S.M., and Gastaldo, R.A., 2000, Taphonomy an Paleobiology: Paleobiology, v. 26, p. 103-147.

BEIER, J.A., 1985, Diagenesis of Quaternary Bahamian beachrock; petrographic and isotopic evidence: Journal of Sedimentary Research, v. 55, p. 755-761.

Best, M.M.R. And Kidwell, S.M., 2000a, Bivalve taphonomy in tropical mixed siliciclastic-carbonate settings, I, environmental variation in shell condition: Paleobiology, v. 26, p. 80-102, doi: 10.1666/0094-8373(2000)026<0080:BTITMS >2.0.CO;2.

Best, M.M.R. And Kidwell, S.M., 2000b, Bivalve taphonomy in tropical mixed siliciclastic-carbonate settings, II, effect of bivalve life habits and shell types: Paleobiology, v. 26, p. 103-115, doi: 10.1666/0094-8373(2000)026<0103: BTITMS $>2.0 . \mathrm{CO} ; 2$.

BEST, M.M., 2008, Contrast in preservation of bivalve death assemblages in siliciclastic and carbonate tropical shelf settings: PALAIOS, v. 23, p. 796-809.

Bishop, D. And Greenstein, B.J., 2001, The effects of Hurricane Floyd on the fidelity of coral life and death assemblages in San Salvador, Bahamas: does a hurricane leave a signature in the fossil record?, in North-Central Section 35th Annual Meeting: Geological Society of America, Abstracts with Programs, Illinois, p. A51.

Brett, C.E., Parsons-Hubbard, K.M., Walker, S.E., Ferguson, C., Powell, E.N., Staff, G.M., Ashton-Alcox K.A., and Raymond, A., 2011. Gradients and patterns of sclerobionts on experimentally deployed bivalve shells: synopsis of bathymetric and temporal trends on a decadal time scale: Palaeogeography, Palaeoclimatology, Palaeoecology, v. 312 , p. $278-304$.

BRILL, A.L., 1993, Modern and ancient carbonate beach-dune systems on the windward side of San Salvador Island, the Bahamas, in Keck Research Symposium in Geology: Abstracts volume, p. 58-61.

Buchan, K.C., 2000, The Bahamas: Marine Pollution Bulletin, v. 41, p. 94-111.

Buchan, O.C., 2006, Relationships between large benthic foraminifera and their seagrass habitats, San Salvador, Bahamas: Unpublished M.S. thesis, Auburn University, Auburn, $86 \mathrm{p}$.

CAdÉE, G.C., 1968, Molluscan biocoenoses and thanatocoenoses in the Ria de Arosa, Galicia, Spain: Zoologische Verhandelingen, v. 95, p. 1-121.

Callender, W.R., Staff, G.M., Parsons-Hubbard, K.M., Powell, E.N., Rowe, G.T., Walker, S.E., Brett, C.E., Raymond, A., Carlson, D.D., White, S., and Heise, E.A., 2002, Taphonomic trends along a forereef slope: Lee Stocking Island, Bahamas, I, location and water depth: PALAIOS, v. 17, p. 50-65.

Carney, C., Dominic, D., Egan, K., and Boardman, M., 1991, Delineation of calcitecemented layers in Holocene skeletal carbonate sands, San Salvador, Bahamas: American Association of Petroleum Geologists Eastern Section Meeting, Pittsburgh, p. 8.
Chattopadhyay, D., Rathie, A., and Das, A., 2013, The effect of morphology on postmortem transportation of bivalves and its taphonomic implications: PALAIOS, v. 28 , p. 203-209, doi: 10.2110/palo.2012.p12-103r.

Chave, K.E., 1964, Skeletal durability and preservation, in J. Imbrie and N. Newell (eds.), Approaches to Paleoecology: John Wiley and Sons, New York, p. 377-387.

Clark, D.D., Mylroie, J.E., And Carew, J.L., 1989, Texture and composition of Holocene beach sediment, San Salvador Island, Bahamas, in J.E. Mylroie (ed.), Proceedings of the Fourth Symposium on the Geology of the Bahamas: Bahamian Field Station, Port Charlotte, FL, p. 83-94.

Cummins, H., Powell, E.N., Stanton JR., R.J., And Staff, G.M., 1986, The size-frequency distribution in palaeoecology: effects of taphonomic processes during formation of molluscan death assemblages in Texas bays: Palaeontology, v. 29, p. 495-518.

Curran, H.A., Greenstein, B.J., White, B., And Wilson, M.A., 1993, San Salvador Island, Bahamas: a natural laboratory for the study of carbonate sediments and rocks-Part IV: Keck Research Symposium in Geology, Abstracts volume, p. 215-219.

Darroch, S.A.F., Locatelli, E.R., McCoy, V.E., Clark, E.G., Anderson, R.P., Tarhan, L.G., AND HulL, P.M, 2016, Taphonomic disparity in foraminifera as a paleo-indicator for seagrass: PALAIOS, v. 31 , p. $242-258$

DeVictor, S.T., Knott, D.M., and Crowe, S.E., 2010, South Carolina Beachcomber's Guide, A Guide to the Common Invertebrates, Plants and Natural Artifacts of the South Carolina Seashore: South Carolina Department of Natural Resources, Charleston, $93 \mathrm{p}$

Feige, A. And Fürsich, F. T., 1991, Taphonomy of the Recent molluscs of Bahia la Choya (Gulf of California, Sonora, Mexico): Zitteliana, v. 18, p. 89-133.

Feser, K.M. AND Miller, A.I., 2014, Temporal dynamics of shallow seagrass-associated molluscan assemblages in St. Croix, US Virgin Islands: toward the calibration of taphonomic inertia: Palaios, v. 29, p.218-230.

Fraser, N. And Greenstein, B.J., 1993, Taphofacies analysis of modern molluscan facies; Bonefish Bay and Snow Bay, San Salvador Island, Bahamas, in Northeastern Section, 28th Annual Meeting: Geological Society of America, Abstracts with Programs, p. 16

Friedman, G.M., 1998, Rapidity of marine carbonate cementation-implications for carbonate diagenesis and sequence stratigraphy: perspective: Sedimentary Geology, v. 119 , p. $1-4$

Fürsich, F.T. AND Flessa, K.W., 1987, Taphonomy of tidal flat molluscs in the Northern Gulf of California: paleoenvironmental analysis despite the perils of preservation: The Paleontological Society Special Publications, v. 2, p. 200-237, doi: 10.1017/S24752 62200004822

Garcia-Ramos, D.A., Albano, P.G., Harzhauser, M., Piller, W.E., and Zuschin, M., 2016 High dead live mismatch in richness of molluscan assemblages from carbonate tidal flats in the Persian (Arabian) Gulf: Palaeogeography, Palaeoclimatology, Palaeoecology, v. 457, p. $98-108$

Gerace, D.T., Ostrander, G.K., and Smith, G.W., 1998, San Salvador, Bahamas, in B Kjerfve (ed.), CARICOMP-Caribbean Coral Reef, Seagrass and Mangrove Sites: UNESCO, Paris, p. 229-245.

Gilad, E., Kidwell, S.M., Benayahu, Y., and Edelman-Furstenberg, Y., 2018 Unrecognized loss of seagrass communities based on molluscan death assemblages: historic baseline shift in tropical Gulf of Aqaba, Red Sea: Marine Ecology Progress Series, v. 589 , p. $73-83$.

Glover, C.P. AND Kidwell, S.M., 1993, Influence of organic matrix on the post-mortem destruction of molluscan shells: The Journal of Geology, v. 6, p. 729-747.

Gosner, K.L., 1999. A Field Guide to the Atlantic Seashore: Houghton Mifflin, New York, $329 \mathrm{p}$.

Horwitz, M. AND RoBerTs, T., 2010, Geomorphic zoning and eogenetic karst on limestones within the supratidal environment: San Salvador, Bahamas: Studia Universitatis BabesBolyai, Geologia, v. 55, p. 17-27, doi: 10.5038/1937-8602.55.1.3.

KIDwELL, S.M., 2001, Ecological fidelity of molluscan death assemblages, in J.Y. Aller, S.A. Woodin, and R.C. Aller (eds.), Organism-Sediment Interaction: University of South Carolina Press, Columbia, p. 199-221.

KIDWELL, S.M., 2002, Mesh-size effects on the ecological fidelity of death assemblages: a meta-analysis of molluscan live-death studies: Geobios, v. 35, p. 107-119, doi: 10.1016/ S0016-6995(02)00052-9

KIDWELL, S.M., 2013, Time-averaging and fidelity of modern death assemblages: building a taphonomic foundation for conservation palaeobiology: Palaeontology, v. 56, p. 487 522.

Kidwell, S.M. and Behrensmeyer, A.K., 1988, Overview: ecological and evolutionary implications of taphonomic processes: Palaeogeography, Palaeoclimatology, Palaeoecology, v. 63, p. 1-13, doi: 10.1016/0031-0182(88)90087-9.

Kidwell, S.M. and Flessa, K.W., 1996, The quality of the fossil record: populations, species, and communities: Annual Review of Earth and Planetary Sciences, v. 24, p 433-464, doi: 10.1146/annurev.earth.24.1.433.

Kidwell, S.M., Rothfus, T.A., AND Best, M.M.R., 2001, Sensitivity of taphonomic signatures to sample size, sieve size, damage system, and target taxa: PALAIOS, v. 16, p $26-52$.

KIM, N., 2001, Petrographic characteristics of a Holocene carbonate grainstones in southeast San Salvador, Bahamas: implications for the sediment reworking in a high energy lagoon: Geosciences Journal, v. 5, p. 349-359, doi: 10.1007/BF02912706.

KindleR, P. AND BaIN, R.J., 1993, Submerged upper Holocene beachrock on San Salvador Island, Bahamas: implications for recent sea-level history: Geologische Rundschau, v. 82 , p. $241-247$. 
Kosnik, M.A., Hua, Q., Jacobsen, G.E., Kaufman, D.S., And Wüst, R.A., 2007, Sediment mixing and stratigraphic disorder revealed by the age-structure of Tellina shells in Great Barrier Reef sediment: Geology, v. 35, p. 811-814, doi: 10.1130/G23722A.1.

Kosnik, M.A., Kaufman, D.S., AND HuA, Q., 2013, Radiocarbon-calibrated multiple amino acid geochronology of Holocene molluscs from Bramble and Rib Reefs (Great Barrier Reef, Australia): Quaternary Geochronology, v. 16, p. 73-86, doi: 10.1016/j.qua geo.2012.04.024.

Kowalewski, M., Flessa, K.W., And Aggen, J.A., 1994, Taphofacies analysis of recent shelly cheniers (Beach Ridges), Northeastern Baja California, Mexico: Facies, v. 31, p. 209-242.

KowalEwski, M., 1996, Taphonomy of a living fossil: the lingulide brachiopod Glottidia palmeri Dall from Baja California, Mexico: PALAIOS, v. 11, p. 244-265.

Kowalewski, M. AND Hoffmeister, A.P., 2003, Sieves and fossils: effects of mesh size on paleontological patterns: PALAIOS, v. 18, p. 460-469.

Kowalewski, M., Hoffmeister, A.P., Baumiller, T.K., and Bambach, R.K., 2005, Secondary evolutionary escalation between brachiopods and enemies of other prey: Science, v. 308, p. 1774-1777, doi: 10.1126/science.1113408.

LAzo, D.G., 2004, Bivalve taphonomy: testing the effect of life habits on the shell condition of the littleneck clam Protothaca (Protothaca) staminea (Mollusca: Bivalvia): PALAIOS, v. 19 , p. $451-459$.

Legendre, P. And Legendre, L., 2012, Numerical Ecology, third edition: Elsevier, Amsterdam, $990 \mathrm{p}$.

Loizeaux, N.T., Curran, H.A., and Fox, W.T., 1993, Seasonal sediment migration and sediment dynamics on Sandy Point Beach, San Salvador Island, Bahamas, in B. White and D.T. Gerace (eds.), Proceedings of the Sixth Symposium on the Geology of the Bahamas: Bahamian Field Station, San Salvador, Bahamas, p. 83-93.

Martinelli, J.C., Madin, J.S., And KosNiK, M.A., 2016. Dead shell assemblages faithfully record living molluscan assemblages at One Tree Reef: Palaeogeography, Palaeoclimatology, Palaeoecology, v. 457, p. 158-169.

Meldahl, K.H. and Flessa, K.W., 1990, Taphonomic pathways and comparative biofacies and taphofacies in a Recent intertidal/shallow shelf environment: Lethaia, v. 23, p. $43-$ 60, doi: 10.1111/j.1502-3931.1990.tb01780.x.

Moore, H.B. And Lopez, N.N., 1969, The ecology of Chione cancellata: Bulletin of Marine Sciences, v. 19, p. 131-148.

NAWROT, R., 2012, Decomposing lithification bias: preservation of local diversity structure in recently cemented storm-beach carbonate sands, San Salvador, Bahamas: PALAIOS, v. 27 , p. $190-205$.

Oksanen, J., Guillaume Blanchet, F., Kindt, R., Legendre, P., Minchin, P. O’Hara, R.B., Simpson, G.L., Solymos, P., Stevens, M.H.H., and Wagner H., 2016, Vegan: community ecology package $\mathrm{R}$ package version 2.3-3: URL https:/CRAN.R-project.org/pack age=-vegan.

OlsZeWSKI, T.D. AND West, R.R., 1997, Influence of transportation and time-averaging in fossil assemblages from the Pennsylvanian of Oklahoma: Lethaia, v. 30, p. 315-329, doi: 10.1111/j.1502-3931.1997.tb00475.x.

Parsons-HubBard, K.M., 2005, molluscan taphofacies in recent carbonate reef/lagoon systems and their application to sub-fossil samples from reef cores: PALAIOS, v. 20, p. 175-191, doi: 10.2110/palo.2003.p03-105.

Parsons, K.M. AND Brett, C.E., 1991, Taphonomic processes and biases in modern marine environments: an actualistic perspective on fossil assemblage preservation, in S.K. Donovan (ed.), The Processes of Fossilization: Columbia University Press, New York, p. 22-65.

Peres-Neto, P.R. And JACKSON, D.A., 2001, How well do multivariate data sets match? The advantages of a procrustean superimposition approach over the Mantel test: Oecologia, v. 129, p. 169-178.

Popov, S.V., 1986, Composite prismatic structure in bivalve shell: Palaeontologica, v. 31, p. $3-26$

Powell, E.N., Parsons-Hubbard, K.M., Callender, W.R., Staff, G.M., Rowe, G.T., Brett, C.E., Walker, S.E., Raymond, A., Carlson, D.D., White, S., and Heise, E.A., 2002 Taphonomy on the continental shelf and slope: two-year trends - Gulf of Mexico and Bahamas: Palaeogeography, Palaeoclimatology, Palaeoecology, v. 184, p. 1-35, doi: 10.1016/S0031-0182(01)00457-6.

Powell, E.N., Staff, G.M., Callender, W.R., Ashton-Alcox, K.A. Brett, C.E., ParsonsHubbard, K.M., Walker, S.E., and Raymond, A., 2011, Taphonomic degradation of molluscan remains during thirteen years on the continental shelf and slope of the northwestern Gulf of Mexico: Palaeogeography, Palaeoclimatology, Palaeoecology, v 312, p. 209-232.

Pruss, S.B., Stevenson, M., And Duffey, S., 2011, Drilling predation and taphonomy in modern mollusk death assemblages, San Salvador Island, Bahamas: Palaeogeography, Palaeoclimatology, Palaeoecology, v. 311, p. 74-81, doi: 10.1016/j.palaeo.2011.08.003.
Quinn, G.P. And Keough, M.J., 2002, Experimental Design and Data Analysis for Biologists: Cambridge University Press, Cambridge, 537 p.

R Core Team, 2015, R, A Language and Environment for Statistical Computing: R Foundation for Statistical Computing, http://www.r-project.org/.

Ritter, M.D.N., Erthal, F., and Coimbra, J.C., 2019, Depth as an overarching environmental variable modulating preservation potential and temporal resolution of shelly taphofacies: Lethaia, v. 52, p. 44-56.

Ritter, M.N., Erthal, F., Kosnik, M.A., Coimbra, J.C., and Kaufman, D.S., 2017, Spatial variation in the temporal resolution of subtropical shallow-water molluscan death assemblages: PALAIOS, v. 32, p. 572-583, doi: 10.2110/palo.2017.003.

Smith, A.M. AND Nelson, C.S., 2003, Effects of early sea-floor processes on the taphonomy of temperate shelf skeletal carbonate deposits: Earth-Science Reviews, v. 63, p. 1-31.

Speyer, S.E. AND BRETt, C.E., 1988, Taphofacies models for epeiric sea environments: middle Paleozoic examples: Palaeogeography, Palaeoclimatology, Palaeoecology, v. 63, p. 225-262, doi: 10.1016/0031-0182(88)90098-3.

Staff, G.M., Callender, W.R., Powell, E.N., Parsons-Hubbard, K.M., Brett, C.E., Walker, S.E., Carlson, D.D., White, S., Raymond, A., and Heise, E.A., 2002, Taphonomic trends along a forereef slope: Lee Stocking Island, Bahamas, II, time: PALAIOS, v. 17 , p. 66-83.

Stanley, S.M., 1970, Relation of Shell Form to Life Habits of the Bivalvia (Mollusca): Geological Society of America Memoirs, v. 125, 296 p.

TAYlor, J.D., KennedY, W.J., And Hall, A., 1969, The shell structure and mineralogy of the Bivalvia, Introduction, Nuculacea-Trigonacea: Bulletin of the British Museum of Natural History, Zoology Series, Supplement 3, p. 1-125.

Thomason, J., Niemi, T.M., McCabe, J., Goucher, J., And Dahne, A., 2005, Beach accretion and erosion caused by the storm surge of the September 2, 2004, Hurricane Frances on the island of San Salvador, Bahamas, in 13th Conference on the Geology of the Bahamas and Other Carbonate Islands: Geological Society of America, Abstracts with Programs, San Salvador, The Bahamas, $66 \mathrm{p}$.

TOMAŠOVÝch, A., 2004, Effect of extrinsic factors on biofabric and brachiopod alteration in a shallow intraplatform carbonate setting (Upper Triassic, West Carpathians): PALAIOS, v. 19, p. 349-371, doi: 10.1669/0883-1351(2004)019<0349:EOEFOB > 2.0.CO;2.

TOMAŠOvÝch, A. AND Rothfus, T.A., 2005, Differential taphonomy of modern brachiopods (San Juan Islands, Washington State): effect of intrinsic factors on damage and community-level abundance: Lethaia, v. 38, p. 271-292, doi: 10.1080/00241160 510013358 .

TOMAŠOVÝCH, A. AND ZuSCHIN, M., 2009, Variation in brachiopod preservation along a carbonate shelf-basin transect (Red Sea and Gulf of Aden): environmental sensitivity of taphofacies: PALAIOS, v. 24, p. 697-716, doi: 10.2110/palo.2009.p09-018r.

Tomašovích, A., Kidwell, S.M., Barber, R.F., and Kaufman, D.S., 2014, Long-term accumulation of carbonate shells reflects a 100-fold drop in loss rate: Geology, v. 42, p. 819-822.

TomašovÝch, A., Schlögl, J., Biroň, A., HudÁčKovÁ, N., AND Mikuš, T., 2017, Taphonomic clock and bathymetric dependence of cephalopod preservation in bathyal, sedimentstarved environments: PALAIOS, v. 32, p. 135-152, doi: 10.2110/palo.2016.039.

Voegeli, V.J., Simonti, A.L., And Curran, H.A., 2006, Seasonal sediment transport and unusually large spit development at Sandy Point, San Salvador, Bahamas, in R.L. Davis and D. Gamble (eds.), Proceedings of the 12th Symposium of the Geology of the Bahamas and Other Carbonate Regions: Gerace Research Center, San Salvador, p. 233240

WAINWRIGHT, S.A., 1969, Stress and design in bivalved mollusc shell: Nature, v. 224, p. 777-779, doi: 10.1038/224777a0.

Warton, D.I., Wright, S.T., AND WANG, Y., 2012, Distance-based multivariate analyses confound location and dispersion effects: Methods in Ecology and Evolution, v. 3, p. 89101 .

Witherington, B. And Witherington, D., 2011, Living Beaches of Georgia and the Carolinas. A Beachcomber's Guide: Pineapple Press Inc., Sarasota, 342 p.

Wright, V.P. AND Burchette, T.P., 1996, Shallow water carbonate environments, in H.G. Reading (ed.), Sedimentary Environments: Processes, Facies and Stratigraphy: Blackwell Science, Oxford, p. 325-391.

Zuschin, M., Hohenegger, J., And Steininger, F.F., 2000, A comparison of living and dead molluscs on coral reef associated hard substrata in the northern Red Sea-implications for the fossil record: Palaeogeography, Palaeoclimatology, Palaeoecology, v. 159, p. 167190, doi: 10.1016/S0031-0182(00)00045-6.

Received 10 April 2019; accepted 18 May 2019. 